\title{
CHRZEŚCIJAŃSKA FILOZOFIA HISTORII W UJĘCIU JAKUBA MARITAINA
}

\section{(Studium krytyczne)}

Ks. (obecnie kard.) Karol Journet nie spodziewał się zapewne tego, że przez swój art. D'une philosophie chrétienne de l'histoire et de la culture, poświęcony poglądom Jakuba Maritaina w wymienionym zakresie ${ }^{1}$, pobudzi tego myśliciela do osobnego, bardziej pogłębionego potraktowania filozofii historii, wziętej w rozumieniu filozofii d ziejów ${ }^{2}$, którą on dotąd uprawiał dorywczo i w sposób fragmentaryczny przy okazji innych zagadnień. A jednak - jak stwierdza sam Maritain ${ }^{3}$ - artykuł ks. Journeta odegrał taką rolę pobudzającą. Gdy bowiem w r. 1955 Maritain zdecydował się za zachętą o. Bernarda J. Mullahy, który stał wtedy na czele Wydziału Filozoficznego katolickiego uniwersytetu Notre Dame (Indiana), poruszyć na tej uczelni, w ramach czterech wykładów, problematykę filozofii historii, wówczas wydatnie dopomógł sobie w przygotowaniu owych wykładów artykułem ks. Journeta, dającym mu syntezę jego refleksji historiozoficznych, na jaką on sam dotąd się ni€ zdobył.

Wykłady, które Maritain wygłosił w języku angielskim, zostały utrwalone na taśmie. Józef W. Evans zestawił ich tekst, biorąc pod uwage

1 Artykuł ten został zamieszczony w pracy zbiorowej Jacques Maritain, son oeuvre philosophique, Bibliothèque de la Revue Thomiste, Paris [1949], 33-61.

Ks. Journet powrócił jeszcze do tej samej problematyki w art.: La philosophie de l'histoire, w: Jacques Maritain. Recherches et débats du Centre des intellectuels français, Paris 1957, cahier n. 19.

2 Wyrażenie ,la philosophie de l'histoire" pochodzi od Woltera. Zob. w Vocabulaire technique et critique de la philosophie Andrzeja Lalande'a, Paris 19475, $754-755$, Wolterowskie rozumienie filozofii. Na wieloznaczność terminu „filozofia historii" zwracal ostatnio uwagę Stefan Swieżawski (Zagadnienie historii filozofii, Warszawa 1966,460$)$.

3 On the Philosophy of History, edited by Joseph W. Evans, New York 1957, X. 
zarówno to, co zostało zapisane w czasie wykładów, jak równiez nie zanotowane w aparacie wypowiedzi Maritaina, sformułowane w trakcie dyskusji, jaka miała miejsce po wykładach, - przy czym poprawił styl angielski swego francuskiego przyjaciela, zachowując jednak charakterystyczny dla jego wykładów ton prostej konwersacji. Gdy Maritain otrzymał od Evansa tekst swych wykładów do przejrzenia, spostrzegł się, że, dysponując w ich ramach czasem bardzo ograniczonym, pominął w nich niektóre punkty — według niego - o dużym znaczeniu. Stąd też jego rewizja tekstu zasadzała się głównie na napisaniu nowych stronic, dzięki którym rozwijane wywody zyskały na większej pełności ${ }^{4}$.

W ten sposób, przy współudziale Evansa, powstała książka Maritaina On the Philosophy of History, wydana drukiem w r. 1957 w Nowym Yorku ${ }^{5}$. Na język francuski przełożył ją ks. Journet ${ }^{6}$. Maritain czytał to tłumaczenie przed jego ogłoszeniem, konfrontując je, wiersz po wierszu, $z$ oryginałem ${ }^{7}$.

Chociaż wskazana książka Maritaina jest w jakiejś mierze krokiem naprzód w kierunku pogłębienia przez niego zagadnień z zakresu filozofii historii, to jednak to, co znajdujemy w tej książce, są to raczej więcej lub mniej dorywcze, niepelne refleksje na temat wymieniony w jej tytule. Dodatnią ich stroną jest to, że mają charakter podstawowy i są dalekie od jakiejś przedwczesnej systematyzacji ${ }^{8}$. Refleksje te mogłyby ewentualnie znaleźć w pewnym zakresie uwzględnienie przy bardziej systematycznym i głębiej umotywowanym opracowaniu filozofii historii.

W niniejszym artykule chciałbym przedstawić uwagi krytyczne, jakie nasuwają się w przedmiocie tego rodzaju spożytkowania sugestii rzuconych przez Maritaina. Najpierw omówię krytycznie Maritainową teorię i metodologię filozofii historii ( $(1)$, następnie przejdę do przeanalizowania praw, wziętych w znaczeniu prawidłowości, które - zdaniem francuskiego myśliciela - charakteryzują historię ludzką (§ 2), a z kolei poruszę, jak - w jego ujęciu - przedstawia się zagadnienie stosunków między wolnością Bożą a wolnością ludzką w kształtowaniu historii (§ 3)

4 Szczególy te podaję za przedmową Maritaina do jego dzieła cyt. wyż., IX.

5 Przez Charles Scribner's Sons, in 8, ss. XI + 180. Angielskie wydanie książki ukazało się w r. 1959 w Londynie, u Geoffrey Bles, ss. XI + 143. Na jęz. hiszp. tłum. Jorge L. García Venturini i Eduardo K. Kraemer, Buenos Aires 1960. Tłum. port. Edgara Godoi da Mata - Machado pt. Sõbre a filosofia da história, Sāo Paulo 1962, ss. 175, 1967, ss. 170. Tłum. Włoskie E. Maccagnolo pt. Per una filosofia della storia, Brescia 1967, ss. 142.

Por. artykuły Maritaina: De la philosophie de l'histoire, „Nova et Vetera”, 32 (1957) 1-27; Des lois de l'histoire. Formules axiomatiques et lois fonctionnelles, tamże, $170-189$.

${ }^{6}$ Pour une philosophie de l'histoire, Paris, éd. du Seuil, 1959, in 16 ${ }^{\circ}$, ss. 190.

7 Zob. s. 9 tłumaczenia, przyp.

8 Uwagi krytyczne Maritaina o omawianej książce zdają się być bardzo trafne. Zob. On the Philosophy of History, 165 (Pour une philosophie de l'histoire, 173). 
oraz problem celów naturalnych historii świata, rozpatrywanych w relacji do celu nadprzyrodzonego człowieka $(\S 4)^{9}$. Specjalne podkreślenie znajdzie w przedstawionych wywodach gnoseologiczny aspekt zag a d ni eń.

§ 1. TEORIA I METODOLOGIA FILOZOFII HistoRII W UJĘCIU MARITAINA.

\section{I}

1. Filozofia historii stanowi dla Maritaina końcowe zastosowanie wiedzy filozoficznej do jednostkowego rozwoju w czasie wydarzeń dokonujących się wobrębie $1 \mathrm{udzkości}{ }^{10}$. Francuskiemu myślicielowi chodzi tu o zastosowanie wiedzy filozoficznej - całej wiedzy filozoficznej, jak kilkakrotnie podkreśla ${ }^{11}$ - przy którym to zastosowaniu zstępuje się $\mathrm{w}$ pewnym sensie głębiej w element jednostkowy dziejów ludzkich niż to robi sama historia, mimo że w porównaniu $\mathrm{z}$ nią filozofia historii posługuje się pojęciami bardziej abstrakcyjnymi i bardziej ogólnymi. Tłumaczy się to tym, że podczas gdy historia usiłuje zbliżyć się bezpośrednio do tego, co ma charakter jednostkowy, co więc nigdy nie daje się w pełni ując na drodze intelektualnej, to filozofia historii, która rezygnuje z poznania tego elementu wziętego w jego jednostkowości, podejmuje się jego poznania w sposób pośredni w tym sensie, że ujmuje go na drodze pojęciowej, a więc prawdziwie intelektualnej, o ile jest on punktem spotkania się pewnych typowych aspektów ogólnych, wspomagających nas w zrozumieniu danej jednostki, jaką w określonym przypadku bierzemy pod uwagę ${ }^{12}$.

Filozofia historii jest więc dla Maritaina $\mathrm{n}$ a u ką, która jest wyrazem próby scharakteryzowania, zinterpretowania lub odczytania w jakiejś mierze historii pod względem jej niektórych aspektów o g ól n y c h, takich jak sens, znaczenie rozwoju wydarzeń ludzkich w czasie, jak pewne kierunki dążén podejmowanych

9 Maritainową koncepcję chrześcijańskiej filozofii historii rozpatrywali $\mathrm{m}$. in. poza ks. Journetem: B. Schwarz, J. Maritain und die christliche Geschichtsphilosophie, "Schweizer Rundschau", Einsiedeln, 37 (1937) 473-480; C. F. Maciel, Maritain e a filosofia da historia, „A Ordem", Rio de Janeiro, 59 (1958) 435-438; R. M. Coffey, rec. W ,The Thomist”, 21 (1958) 569-574; C. P. Loughran, rec. w ,Thought”, New York, 33 (1958) 141-143; Thomas D. Langan, Some Truths and Truisms regarding History, "Review of Metaphysics”, New Haven (Conn.), 12 (1958-1959) 277-284; Leszek Kolakowski, Chrześcijańska filozofia historii (2), ,Argumenty”, 4 (1960), nr 14 (95) z dnia 3 IV; A. Hayen, rec. w „Nouvelle Revue Théologique", 83 (1961) 871-872; C. Golfin, rec. W „Revue Thomiste”, 65 (1965) 142-145. 10 On the Philosophy of History, 13-14, 17, 19 (Pour une philosophie de l'histoire, 26-28, 31-33).

11 Filozofia historii w ujęciu Maritaina zakłada - jak zobaczymy - nie tylko metafizykę, ale również filozofię przyrody.

12 On the Philosophy of History, 14-16 (Pour une philosophie de l'histoire, $28-30)$. 
przez ludzkość, jak prawa zdolne oświetlić wydarzenia historyczne bez ich zdeterminowania. Te aspekty ogólne, stanowiące cel badań filozofii historii, mają zawsze - według umiarkowanie maksymalistycznego ujęcia Maritaina - charakter fragmentaryczny i są zawsze jakoś niepowiązane ze sobą. Francuski tomista sądzi, że jest to następstwem tego, iż historia nie jest dla jej filozofii problemem do rozwiązania, lecz tajemnicą do rozmyślania. Zdaniem Maritaina ta tajemnica posiada do pewnego stopnia charakter ponadrozumowy, o ile historia ludzka zależy od planów Bożych. W pewnej znów mierze owa tajemnica ma dotyczyć płaszczyzny znajdującej się poniżej rozumu ludzkiego, o ile historia obejmuje $\mathrm{w}$ biegu swych wydarzeń materię oraz przygodność, i o ile jej bieg ulega wypaczeniu na skutek złego użytku wolności ludzkiej. Stąd też, zdaniem Maritaina, filozofia historii nie może nam dać rozumowego wytłumaczenia historii, ani też nie jest w stanie dokonać jej rekonstrukcji według praw o charakterze konieczności ${ }^{13}$.

2. W sposób bardziej techniczny Maritain określa osnowę filozofii historii przez wskazanie jej „,podmiotu materialnego" (the subject matter) oraz jej ,przedmiotu formalnego" (the formal object) ${ }^{14}$.

„Podmiotem materialnym" filozofii historii są - w ujęciu francuskiego autora - poszczególne jednostki ludzkie i jednostkowe wy darzeni a składające się na dzieje ludzkie. Filozofia historii ma więc - według Maritaina - ten sam ",podmiot materialny” co historia, a różni się od niej jedynie swym „przedmiotem formalnym”, na który mają się składać typowe rysy danego okresu historycznego albo pewne cechy istotne his torii ludzkiej $\mathrm{w}$ ogólności (the typical features of a given historical age or some essential aspect of human history in general) ${ }^{15}$. Najzwięźlej określa Maritain ,przedmiot formalny” filozofii historii jako to, co w dziejach można uważać za intelligible „quiddities” or raisons d'être ${ }^{\mathbf{1 6}}$.

3. Gdy idzie o metodę filozofii historii, to Maritain na pierwsze miejsce wysuwa ind ukcję, która — według niego — prowadzi do wykrycia w empirycznym elemencie jednostkowym dziejów ludzkich pewnych struktur, dających się wyrazić abstrakcyjnie w trakcie ich inte-

13 On the Philosophy of History, 2, 15, 31-32 (Pour une philosophie de l'histoire, $16,29,44-45)$.

14 Maritain nawiązuje tu do dawnych scholastyków, którzy rozróżniali między „podmiotem" nauki a jej ,przedmiotem”. „Podmiotem” byla dla nich rzecz, do której dana nauka zwraca swe badania, natomiast za „przedmiot” nauki uważali wnioski i prawdy, jakie ona ustala w odniesieniu do owej rzeczy. Maritain wyraża się wszakże w Sept leçons sur l'être et les premiers principes de la raison spéculative (Paris [brw], 88), że można nie liczyć się z tym rozróżnieniem przy przeprowadzaniu klasyfikacji nauk.

15 On the Philosophy of History, 4-5, 9, 35, 38 (Pour une philosophie de l'histoire, 18-19, 23, 48-49, 50-51).

16 On the Philosophy of History, 5 (Pour une philosophie de l'histoire, 19). 
lektualnego poznania ${ }^{17}$. Jak się zdaje, mówiąc o indukcji, ma Maritain na uwadze indukcję enumeracyjną niezupełną, którą trzeba uznać za wyraz rozumowania redukcyjnego, prowadzącego do wniosku więcej lub mniej prawdopodobnego. Francuski tomista sądzi ${ }^{18}$, że sposób, w jaki Arnold Toynbee charakteryzuje wielkie cywilizacje, jest dobrym przykładem tego, jakie możliwości kryje w sobie wskazana indukcja przy wykrywaniu niektórych typowych cech dziejów ludzkich.

Co do bazy wyjściowej indukcji, to - zdaniem Maritaina - poczesne miejsce zajmuje w niej etnologia. Określając ją skrótowo terminem „the anthropology” (ściślej byłby ją określił w linii anglosaskich konwencji naukowych jako „social” lub „cultural anthropology"), Maritain pisze 19, że żadna filozofia historii nie może się ukształtować bez ,antropologii”, gdyż ta stanowi dla niej jedną z podstawowych danych (a basic consideration).

Według Maritaina sama indukcja nie wystarcza do rozpracowania przedmiotu formalnego filozofii historii. Francuski myśliciel sądzi, że rezultaty indukcji powinny być poddane filozoficznemu sprawdzeniu, tzn. żè powinno się je skonfrontować $z$ uprzednio zdobytymi prawdami filozoficznymi dotyczącymi natury ludzkiej, by uzyskać dla nich potwierdzenie w tych prawdach ${ }^{20}$. Dzięki filozoficznemu sprawdzeniu rezultatów indukcji dostrzegamy - zdaniem Maritaina — że te rezultaty kryją w sobie pewną konieczność poznawalną intelektualnie, konieczność opartą na naturze rzeczy, która nam ukazuje rację tego, co dokonuje się $\mathrm{w}$ dziejach ludzkości ${ }^{21}$. Maritain nie chce jednak powiedzieć, żeby filozofia historii dochodziła, dokonując konfrontacji rezultatów indukcji

17 On the Philosophy of History, 9, 21-22 (Pour une philosophie de l'histoire, $23,35-36)$.

18 On the Philosophy of History, 9, przyp.

19 Tamże, 96, przyp. 9.

20 On the Philosophy of History, 9-11, 22 (Pour une philosophie de l'histoire, $23-25,35)$.

Przyjęta przez Maritaina metoda filozofii historii, wzięta w swym stadium filozoficznych sprawdzań, przypomina metodę, jaką ten myśliciel przyjął dla filozofii przyrody, która - według niego - powinna znaleźć oparcie nie w surowych faktach naukowych, w faktach ustalonych i sformułowanych przez przyrodnika w świetle charakterystycznego dlań poznania, lecz w faktach „filozoficznych”, tzn. w danych, jakie zostały zebrane i osądzone w świetle obiektywnym filozofii i, dzięki temu, stały się jej „materią” własną, „materią” przez nią przywłaszczoną.

Zob. Maritaina: Science et philosophie d'après les principes du réalisme critique, „Revue Thomiste”, 14 (1931) 38-39; Distinguer pour unir, ou Les degrés du savoir, Paris 1963 7, 114-116, 353-354, 359; La philosophie de la nature - Philosophie et sciences, „La Vie Intellectuelle”, 31 (1934) 252-254; La philosophie de la nature - Essai critique sur ses frontières et son objet, Paris [1935], 136-141; Science et sagesse, Paris 1935, 111; Quatre essais sur l'esprit dans sa condition charnelle. Paris $1956^{2}, 224-225,244-245$.

Por. moje artykuły: Aktualne kontrowersje w zakresie prolegomenów do filozofii przyrody, „Zeszyty Naukowe KUL”, 3 (1960, $\mathrm{nr} 2$ ) 25-30; Metoda filozofii przyrody $w$ neoscholastyce, ,Roczniki Filozoficzne”, 8 (1961, z. 3) 5-36.

21 On the Philosophy of History, 9 (Pour une philosophie de l'histoire, 23). 
z określonymi prawdami filozoficznymi, do samej pewności. Przeciwnie, podkreśla, że w obrębie filozofii historii występuje spora doza czynnika przypuszczeń lub hi potez. Doza tego czynnika jest - zdaniem Maritaina - tym większa, im wydatniej zaznacza się $w$ ramach filozofii historii udział czystej indukcji 22.

Wiedząc, jak najogólniej przedstawia się wysunięta przez Maritaina teoria i metodologia filozofii historii, zwróćmy $z$ kolei uwagę na wyjątkowe stanowisko, jakie ona - według tego autora - ma zajmować w obrębie poznania historycznego, o ile jest nauką. Jest to kwestia, która narzuca się przed rozpatrzeniem bardziej szczegółowych aspektów gnoseologicznych i metodologicznych - koncepcji podjętej przez francuskiego tomistę.

Maritain utrzymuje, że przedmiot formalny filozofii historii jest j edynym przedmiotem ,naukowym" w sferze poznania his tor y c znego. Jest to bowiem przedmiot odznaczający się abstrakcyjnością, ogólnością i koniecznością, przedmiot, który stawia nas wobec poznawalnych intelektualnie istot rzeczy albo ich racji dostatecznej 23 .

Tych właściwości przedmiot formalny historii — zdaniem Maritaina nie posiada, gdyż ma on zawsze dotyczyć, przynajmniej w ostatniej instancji, tego, co jest jednostkowe, konkretne i przygodne ${ }^{24}$. Jest to idiograficzne ujęcie historii, które francuski filozof znalazł nie tylko $\mathrm{w}$ tradycji tomizmu, ale również u Henryka J. Marrou w jego pracy De la connaissance historique ${ }^{25}$. Jak pisze Maritain, historia

22 On the Philosophy of History, 18 (Pour une philosophie de l'histoire, 32).

23 Zob. w Les degrés du savoir, 47-50, szczegółowe wywody Maritaina dotyczące przedmiotu nauki.

24 On the Philosophy of History, 5 (Pour une philosophie de l'histoire, 19). Zob. jeszcze w oryginale ang. 2 i 14 oraz w tłum. franc. 16-17, 28.

Zdaniem Maritaina nauka nie zajmuje się bezpośrednio jednostkowym jako takim.

Nie chce jednak francuski tomista powiedzieć, żeby nie można było mieć o jednostkowym jako takim intelektualnego poznania pośredniego, urzeczywistnionego w drodze, „refleksji” nad danymi zmysłów lub za pośrednictwem współnaturalności uczuciowej. Przyjmuje nawet, idąc za Janem od św. Tomasza, że o jednostkowym możemy mieć pojęcie w ścisłym tego słowa znaczeniu, które jednakże będzie odnosiło się do jednostkowego w sposób pośredni.

Maritain nie twierdzi także, żeby nauka o jednostkowym była niemożliwa, jeżeli tylko tego, co jest jednostkowe, nie będziemy brali w jego jednostkowości. Charakterologia, grafologia, nauka o temperamentach, itd., są - według Maritaina - naukami, w których to, co jest natury indywidualnej, jednostkowej, zostało ujęte „pod siecią ogólnych pojęć pod-gatunkowych" (sous-spécifiques), przy udziale sztuki oraz doświadczenia i dzięki roli odgrywanej przez ratio particularis. Zob. Les degrés du savoir, 56-57, przyp. 2.

25 Maritain korzystał $\mathrm{z}$ wyd. I (Paris 1954). Idiograficznej koncepcji historii Marrou daje $\mathrm{m}$. in. wyraz w wyd. IV z 1959 r. na s. 157, 170. Por. w artykule Wandy Moszczeńskiej O sprzecznościach wewnętrznych ,programowego" subiektywizmu W sprawie ksiażki H. I. Marrou, „Kwartalnik Historyczny”, 65 (1958) 450-452. 
zajmuje się indywidualnymi osobami i indywidualnymi wydarzeniami ${ }^{26}$. Wprawdzie fakty historyczne zakładają i implikują tyleż sądów krytycznych, rozróżnień i przeróbek pojęciowych co wszystkie inne fakty; gdy znów idzie o odtworzenie przeszłości przez historię, to tę przeszłość musi ona poddać interpretacji, musi ją przetransponować na język ludzki i rozłożyć na ciąg wydarzeń wypływających jedno z drugiego, czyli musi dokonać pracy wymagającej dużego udziału abstrakcji; niemniej jednak to, do czego przy pomocy wymienionych środków dąży historia, jest to powiązanie jednostkowego $\mathrm{z}$ jednostkowym. T $\mathrm{lum}$ a c z e ni e, jakie daje historyk jako historyk, jest to - według Maritaina - tłumaczenie tego, co ma charakter indywidualny przez to, co równieź posiada taki sam charakter, bo przez indywidualne okoliczności, motywacje i w y arzenia. Takie tłumaczenie, uczestnicząc w nieskończoności potencjalnej materii, nigdy nie jest zakończone, i stąd Maritain o nim utrzymuje, że ono, jako tłumaczenie, nie posiada pewności naukowej ${ }^{27}$.

Maritain więc na tej samej zasadniczo podstawie odmawia historii charakteru nauki, jak to robił spośród nowszych neoscholastyków np. ks. Józef de Tonquédec SJ, który jednak podkreślał, że ta odmowa dotyczy tylko historii w sensie najbardziej ścisłym, tzn. historii będącej poznaniem faktów minionych i ich szczegółowych przyczyn, bo ujęcie ogólnych praw, na jakich wyodrębnienie historia pozwala, ma już charakter właściwego poznania naukowego ${ }^{28}$. W uzasadnieniu tezy o nienaukowości historii Maritain nawiązuje nie tylko do wypowiedzi neoscholastyków, ale również do argumentacji takiego autora spoza nurtu tomistycznego jak Marrou, który utrzymuje, że przeprowadzenie dowodu w ramach poznania historycznego jest rzeczą niemożliwą ${ }^{29}$.

\section{III}

Po uwidocznieniu wyjątkowego stanowiska, jakie - zdaniem Maritaina - zajmuje filozofia historii, jako nauka, w ramach poznania historycznego, chciałbym poddać bardziej szczegółowej analizie koncepcję tego filozofa w jej aspektach gnoseologicznych. Do jej aspektów metodologicznych nie będę wracał, gdyż zostały - jak sądzę - wyczerpująco przedstawione.

${ }_{26}$ On the Philosophy of History, 2, przyp. (Pour une philosophie de l'histoire, 17, przyp.).

27 On the Philosophy of History, 3 (Pour une philosophie de l'histoire, 17). Gdy idzie o ostatnio przytoczone twierdzenie, to Maritain przyznaje jednak, że historia może dojść do pewności w zakresie faktów (is capable of factual certitude).

${ }^{28}$ La philosophie de la nature, première partie: La Nature en général ler fasc.: Prolégomènes, Paris 1956, 90-92. (Chodzi o dodatek: L'histoire est-elle une science?).

29 Dz. cyt., 143. 
1. Filozofia historii nie jest - według Maritaina ${ }^{30}$ - c z ęśs ią metafizy ki, jak utrzymywał Jerzy W. F. Hegel ${ }^{31}$, a z autorów neoscholastycznych - ks. Franciszek Sawicki ${ }^{32}$, ks. Konstanty Michalski $\mathrm{CM}^{33}$ i ks. Ferdynand Van Steenberghen ${ }^{34}$. Niemniej jednak $\mathrm{z}$ a k $\mathrm{k}$ a d a ona metafizykę, a także filozofię przyrody. Zakłada nawet całą filozofię, ,teoretyczną" 35 .

Spośród założeń filozofii historii Maritain specjalnie uwzględnia te, które tłumaczą element pr zyg od n ości, występujący w historii ludzkiej. Są nimi istnienie wolnej woli ludzkiej orazinnych właściwości naszej osoby i istnienie Boga. Maritain sądzi, że bez uwzględnienia pierwszego założenia nie jesteśmy w stanie zrozumieć tego, iż człowiek może wywierać wpływ decydujący na sposób albo na specy-

30 On the Philosophie of History, 37 (Pour une philosophie de l'histoire, 50).

31 Vorlesungen über die Philosophie der Geschichte (polskie tłum. Janusza Grabowskiego i Adama Landmana pt. Wykłady z filozofii dziejów, [bmw] 1958, t. I, 3, 13-25, 89, 117, 297; odnośnie Heglowskiego rozumienia metafizyki, tamże, 24, $39-40,110)$.

Zob. o Heglowskiej filozofii historii w art. Jana Ladrière Histoire et Destiné, „Revue Philosophique de Louvain”, 58 (1960) 108-112.

32 Geschichtsphilosophie, München $1923^{3}$, 3-4.

33 Zagadnienia współczesnej filozofii dziejów (Przemówienie i wykład inauguracyjny Rektora Uniwersytetu Jagiellońskiego na otwarcie roku akad. 1931/2 dn. 11 X 1931 r.), „Przegląd Współczesny”, r. 10, t. 39 (1931) 161-180, odb., Kraków 1931, ss. 22, przedruk $\mathrm{z}$ drobnymi opuszczeniami w tomie pism wybranych ks. Michalskiego Dokad idziemy, Kraków 1964, 34-54; Tomizm wobec współczesnej filozofii dziejów (Referat wygłoszony 28 VIII 1934 r. na pierwszym zebraniu plenarnym międzynarodowego kongresu filozofii tomistycznej w Poznaniu), Magister Thomas - Doctor communis, Księga pamiątkowa międzynarodowego kongresu filozofii tomistycznej w Poznaniu (23-30 sierpnia 1934), Studia Gnesnensia XII, Gniezno 1935, 1-29, odb., Gniezno 1935, ss. $29+2$ stronice ze streszczeniem w jęz. franc., art. przedruk. w zbiorze artykułów ks. Michalskiego pt. Nieznanemu Bogu, Warszawa 1936, 127-165; Dokad idziemy, ,Znak", 1 (1946) 4-25, przedruk. z nieznacznymi opuszczeniami w tomie Dokad idziemy, 15-33.

Wymienione prace omówiłem w studium Analiza twórczości naukowej ks. Konstantego Michalskiego, zamieszczonym w książce: Ks. Aleksander Usowicz CM i ks. Kazimierz Klósak, Konstanty Michalski (1879-1947), Kraków 1949, „Analecta Historica Congregationis Missionis Prov. Polonorum", III, 196-207.

34 Épistémologie, Louvain $1947^{2}$, 256. - Dla ks. Van Steenberghena filozofia historii, filozofia ewolucji historycznej, jest częścią metafizyki szczególowej, dodladniej - metafizyki ludzkiej (antropologii).

Nie zdaje się być uzasadnione twierdzenie Swieżawskiego, że metafizyczne ujęcie filozofii historii jest możliwe tylko na gruncie filozofii apriorystycznej i idealistycznej (dz. cyt., 457-458). Poglądy ks. Sawickiego, ks. Michalskiego i ks. Van Steenkerchona wskazują na to, że również przy filozoficznej orientacji aposteriorycznej i realistycznej można przypisywać filozofii historii charakter metafizyczny. Jeżeli Swieżawski sądzi inaczej, to tłumaczy się tym, że dowolnie przyjmuje, iż ,metafizyka dziejów w sensie teorii metafizycznej, określającej sens, właściwości i cel rozwoju historycznego oraz prawa tego rozwoju", musiałabv mieć genezę niemożliwa do zrealizowania, gdyż albo mogłaby powstać bezpośrednio z rezultatów nauk szczegółowych, albo mogłaby się wywodzić z niezależnej od doświadczenia zmysłowego, uniwersalnej i bezbłędnej wiedzy.

35 On the Philosophy of History, 16-17 (Pour une philosophie de l'histoire, 30). $46-48)$.

On the Philosophy of History, 34-35 (Pour une philosophie de l'histoire, 
ficzną orientację czy inspirację zmian historycznych, będących w sobie, pod względem ogólnego schematu, czymś koniecznym z racji nagromadzenia się odpowiadających im potrzeb. Bez wzięcia pod uwagę drugiego założenia, jakim jest istnienie Boga, nie można znów uważać dziejów ludzkich za kierowane przez Boga, za ksztaiłtowane według Jego odwiecznych planów, umiejących wyprowadzać dobro ze zła moralnego; a w dalszej konsekwencji będzie się zniekształcało dzieje przypisując ich planom immanentnym czy wymaganiom dialektycznym lub koniecznym prawom „,naukowym” to, co trzeba przypisać transcendentnej ingerencji Bożej.

2. Maritain sądzi, że filozofia historii należy do fil o z ofi i mor a ln ej, gdyż jej przedmiotem są czyny ludzkie rozpatrywane tak, jak pojawiają się $\mathrm{w}$ ewolucji ludzkości ${ }^{37}$. Jest więc z racji swego charakteru egzystencjalnego częścią filozofii praktycznej, „mądrości” praktyc znej, dokładniej - spekulatywno-praktycznej ${ }^{38}$.

Mówiąc o filozofii moralnej przy ustalaniu przynależności epistemologicznej filozofii historii, Maritain ma na uwadze filozofię moralną a d e$\mathrm{kw}$ at $\mathrm{nie} \mathrm{wzi}$ tą (the moral philosophy adequately taken, la philosophie morale adéquatement prise), tzn. filozofię moralną uzupełnioną przez dane zapożyczone od teologii, dotyczące warunków egzystencjalnych człowieka w zakresie jego natury (stan pierwotnej niewinności, stan natury upadłej i natury odkupionej) i w zakresie jego różnych stanów historycznych (stan moralny wcześniejszy od prawa pisanego, stan prawa starego, Mojżeszowego, i stan prawa nowego, ewangelicznego) ${ }^{39}$.

Maritain sądzi, że, mimo tych zapożyczeń o charakterze teologicznym, uprawia nie teologię historii, lecz filozofię historii, chociaż jest to $\mathrm{c} \mathrm{h} \mathrm{r}$ z eścijańska filozofia historii. Teologia historii ześrodkowuje się według niego - na królestwie Bożym i historii zbawienia. Wprawdzie rozpatruje nie tylko rozwój Kościoła, ale również rozwój świata, ale ten drugi bierze z punktu widzenia pierwszego. Natomiast filozofia historii koncentruje swe analizy na świecie i historii cywilizacji. Jednakowoż nie pomija przy tych analizach związków łączących tajemnicę świata z Ko-

37 On the Philosophy of History, 16-17, 37 (Pour une philosophie de l'histoire, $30-31,50$ ).

38 On the Philosophy of History, 16-17, 169 (Pour une philosophie de l'histoire, $30,177)$.

Zob. u IMaritaina w Eléments de philosophie, I, Introduction générale à la philosophie, Paris 1930, 189-191, wyjaśnienia dotyczące praktycznego charakteru filozofii moralnej.

39 On the Philosophy of History, 38-40, 78-93 (Pour une philosophie de l'histoire, $51-53,90-104)$.

Koncepcji filozofii moralnej adekwatnie wziętej, rozwijanej przez Maritaina w książkach De la philosophie chrétienne, Paris 1933, 69-77, 108-166 i Science et sagesse, 288-345, 374-385 oraz w art. De la philosophie morale adéquatement prise, „Revue de l'Université d'Otawa”, 2 (1933) 105-134, poświęcilem studium krytyczne Maritainowa analiza stosunku filozofii moralnej do teologii, "Collectanea Theologica", 19 (1938) 177-218. 
ściołem, lub inaczej się wyrażając — z Królestwem Bożym w stanie pielgrzymowania ${ }^{40}$.

Francuski tomista opowiedział się za chrześcijańską filozofią historii najpierw dlatego, że - jego zdaniem - nie ma filozofii historii pełnej albo zrównanej całkowicie ze swym przedmiotem bez uwzględnienia pewnych danych prorockich lub teologicznych. Doszedł tu jeszcze ten wzgląd, że refleksje Maritaina nad filozofią historii wyrastały od wielu lat w szerokim zakresie na gruncie problemu praktycznego kondycji chrześcijan, ich trudności i odpowiedzialności, jakie im przypadają w udziale w społeczności współczesnej. Dążąc do opracowania „ekwipunku” intelektualnego, przy użyciu którego można byłoby odpowiedzieć na te trudności, Maritain doszedł do zwrócenia specjalnej uwagi na dane ponadfilozoficzne ${ }^{41}$.

3. Stanowisko Maritaina $\mathrm{w}$ sprawie pozytywnych powiązań, jakie, według niego, mają zachodzić między filozofią historii a teologią, zbiega się w zasadzie ze stanowiskiem takich autorów o więcej lub mniej odrębnej orientacji, jak Józef Pieper i Mircea Eliade. Pierwszy z nich w książce Über das Ende der Zeit, eine geschichtsphilosophische Meditation (München 1953²) uzależnia - zdaniem Maritaina - zbyt mocno całą myśl filozoficzną od teologii, niemniej jednak utrzymuje tak samo jak on, że ukształtowanie filozofii historii jest niemożliwe bez zapożyczeń ze strony teologii, gdyż zasadniczym przedmiotem refleksji filozoficznych nad historią jest jej cel, a ten nie daje się ująć adekwatnie bez chrześcijańskiej interpretacji teologicznej. Co do Eliade, to on sugeruje w pracy Le mythe de l'éternel retour (Paris 1949), że horyzont archetypów i wiecznego rozpoczynania na nowo może znaleźć bezkarne przekroczenie przy uprawianiu filozofii historii jedynie w klimacie wiary religijnej podzielanej przez chrześcijan, tej wiary, która daje możliwie największą wolność i jest w stanie, niezależnie od swej wartości soteriologicznej, obronić człowieka nowożytnego przed terrorem historii ${ }^{42}$.

Jeszcze więcej zbieżności, niż z Pieperem i Eliade, wykazuje Maritain w stosunku do Dawida B. Richardsona, autora art. The Philosophy of History and the Stability of Civilisations ${ }^{43}$, dla którego również filozofia

40 On the Philosophy of History, 37-38 (Pour une philosophie de l'histoire, $50-51)$.

Gdy idzie o termin „świat”, to on oznacza dla Maritaina kosmos filozofii greckiej i hic mundus Ewangelii. Zob. w tekście angielskim cyt. dzieła s. 170 i w tekście franc. s. 178.

${ }_{41}$ On the Philosophy of History, 170-171 (Pour une philosophie de l'histoire, $178-179)$.

42 On the Philosophy of History, 41-42 (Pour une philosophie de l'histoire, $53-55$ ).

43 "The Thomist", 20 (1957) 158-190. 
historii jest częścią filozofii moralnej, i to filozofii moralnej chrześcijańskiej. Maritain czytał jego artykuł przy korekcie swej książki ${ }^{44}$.

\section{IV}

Zanim przejdę $\mathrm{w}$ drugim paragrafie niniejszego studium do przeanalizowania praw, które - według Maritaina - działają w historii ludzkiej, poruszę zagadnienie wartości jego teorii i metodologiifilozofii historii. Szczegółowe problemy omówię częściowo w innej kolejności niż ta, w jakiej zostały przedstawione. Uczynię to w tym celu, by uzyskać możliwie największą zwartość logiczną poczynionych uwag krytycznych.

1. Zacznę od wstępnego twierdzenia francuskiego tomisty, że w obrębie poznania historycznego, tzn. poznania dotyczącego dziejów ludzkich, przedmiot formalny filozofii historii jest jedynym przedmiotem ,naukowym".

Jak wiemy, Maritain utrzymuje tak dlatego, gdyż — jego zdaniem w historii dziejów ludzkich wszystko jest ostatecznie podporządkowane temu, co posiada charakter jednostkowy, konkretny i przygodny, zaś według Arystotelesa i św. Tomasza z Akwinu nauka [w sensie ścisłym, nauka doskonała, wyidealizowana] nie zajmuje się bezpośrednio tego rodzaju przedmiotem jako takim.

Otóż, jeżeliby nawet przyjęta przez Maritaina charakterystyka przedmiotu formalnego historii była trafna, należałoby zauważyć, że teoria nauki, do jakiej ten filozof się odwołuje, uległa wraz z rozwojem nauk w czasach nowożytnych częściowej dezaktualizacji. Jak pisze Jerzy Kalinowski poddając śmiałej krytyce perypatetyczno-tomistyczną teorię nauki [w podanym wyżej sensie] ${ }^{45}$, szczegółowe nauki realne studiują równie dobrze jednostkowe jako takie jak ogólne, zawarte w jednostkowym. Jest to pos zer z e n i e sensu terminu „,nauka”, którego Maritain wraz $z$ wielu inymi tomistami nie bierze pod uwage pozostając przy węższym rozumieniu Stagiryty i św. Tomasza, modelowanym „,na matematyce, w szczególności na dawnej geometrii” ${ }^{46}$.

44 Zob. On the Philosophy of History, 173, przyp. (Pour une philosophie de l'histoire, 181, przyp.).

45 Esquisse de l'évolution d'une conception de la métaphysique, „Recherches de Philosophie", 6 (1963) 113. - Zob. w rozprawie Jana Łukasiewicza O twórczości $w$ nauce ( $Z$ zagadnień logiki $i$ filozofii - Pisma wybrane, Warszawa 1961, 67) argumentację za koniecznością uwzględniania w nauce sądów jednostkowych.

4u Jest to twierdzenie ks. Piotra Chojnackiego (Dwie koncepcje epistemologiczne metafizyki u w. Tomasza z Akwinu i ich źródła, "Collectanea Theologica”, 34 (1963) 9).

Zob. W przedmiocie Arystotelesowskiej teorii nauki: ks. Chojnacki, Nauka wyidealizowana $i$ nauka faktyczna $w$ epistemologii Arystotelesa. „Sprawozdania Towarzystwa Naukowego Warszawskiego", Wydział II, 40 (1947) 17-29; id., Dwie 
Jest prawdą, co twierdzi Maritain, że to, co ma charakter jednostkowy, nie daje się nigdy, jako takie, ująć intelektualnie w sposób pełny, wyczerpujący. Tak rzecz się ma z racji ogromnego bogactwa szczegółów, których, przy naszym cząstkowym zawsze podejściu poznawczym, nie jesteśmy w stanie wyczerpać w skończonych odcinkach czasu, jakimi dysponujemy ${ }^{47}$. Jednakowoż pełne, wyczerpujące ujęcie intelektualne nie jest konieczne do uprawiania nauki, gdyż dla niej wystarcza ujęcie cząstkowe, w którym dochodzi do głosu nie dająca się przezwyciężyć aspektowość naszego poznania, uwarunkowana stałym dokonywaniem jakichś abstrakcji.

Jest również tak, jak utrzymuje francuski tomista, że gdy historyk tłumaczy to, co ma charakter indywidualny, przez to, co również posiada taki sam charakter, mianowicie przez indywidualne okoliczności, motywacje i wydarzenia - jego tłumaczenie, uczestnicząc w nieskończoności potencjalnej materii, nigdy nie jest całkowicie zakończone. Ale z tego faktu nie wyprowadzimy z Maritainem wniosku, że wskazane tłumaczenie historyka nie ma wartości naukowej, gdyż nie jest pewne. Wszak obecnie sądzimy, że do tego, by danemu tłumaczeniu przyznać wartość naukową, wystarczý, iż posiada ono odpowiednio u zasadniony, taki lub inny, stopień prawdopobieństwa. Już Arystoteles przyjmował, że w ramach faktycznego, nie wyidealizowanego poznania naukowego studiuje się nie tylko to, co jest konieczne i powszechne, ale również to, co zachodzi najczęściej, a więc to, co jest aktualnie przedmiotem nauk stosujących metody statystyczne ${ }^{48}$, czyli nauk będących wyrazem poznania prawdopodobieństwościowego. Współczesnie, poza tomistami nawiązującymi jeszcze do Arystotelesowskiej teorii nauki doskonałej, wyidealizowanej, naukowość probabilistycznego charakteru wyjaśnien historycznych, wysuwanych w przypadku pomijania rozciągłości czasowej konkretnych czynów i okoliczności ich dokonywania się, nie budzi żadnych wątpliwości. Jako przykład można przytoczyć analizy metodologiczne Ernesta Nagela, przeprowadzone w odniesieniu do wskazanych wyjaśnień historycznych ${ }^{49}$.

Nie chciałbym jednak, żeby przedstawiono uwagi krytyczne zostały zrozumiane $\mathrm{w}$ tym sensie, że podzielam bez zastrzeżeń pogląd Maritaina

koncepcje epistemologiczne metafizyki ..., 5-23 (passim); id., Metoda dialektyczna Arystotelesa jako droga do zasadniczych przestanek filozofii i nauki, „Studia Philosophiae Christianae", 1 (1965) 33-49; Tadeusz Kwiatkowski, Poznanie naukowe u Arystotelesa, Warszawa 1969; ks. Stanisław Kamiński, Pojęcie nauki i klasyfikacja nauk, Lublin $1970^{2}$, 58-64.

${ }_{47}$ Infinityzm, jaki tu został zasugerowany w odniesieniu do indywiduów, jest infinityzmem epistemologicznym czy metodologicznym, a nie metafizycznym.

48 Zob. Kwiatkowskiego dz. cyt., 70-71, 201.

49 Struktura nauki - Zagadnienia logiki wyjaśnień naukowych, tłum. z ang. Jerzy Giedymin, Bożydar Rassalski i Helena Eilstein, Warszawa 1970, 472-483. Swe ogólne obserwacje o wyjaśnianiu probabilistycznyu Nagel podaje. na s. 29-30. 
na przedmiot formalny historii jako dyscypliny. Wręcz przeciwnie sądzę, że tego przedmiotu nie stanowi wyłącznie to, co jest jednostkowe, konkretne i przygodne. Można zapewne powiedzieć za Nagelem, że ,,badania historyczne dotyczą przede wszystkim jednostkowych zdarzeń" 50, ale razem $\mathrm{z}$ wymienionym metodologiem zauważymy, że „byłoby [...] grubym błędem utrzymywać, że [...] w badaniach historycznych nie korzysta się wcale z twierdzeń ogólnych" 51. „W naukach historycznych — jak wykazuje Nagel — nie możemy obejść się bez milcząco choćby przyjętych twierdzeń ogólnych w rodzaju tych, jakie formułuje się w rozprawach teoretycznych. Historyk, nawet jeśli zajmuje się tym, co jednostkowe i niepowtarzalne, musi oczywiście dokonywać selekcji i abstrahować od rozmaitych konkretów, na które natrafia w swych badaniach, a traktując - tym, co bezsprzecznie indywidualne, musi używać nazw ogólnych i ogólnych wyrażeń deskryptywnych. Toteż jego charakterystyka tego, co indywidualne, zakłada istnienie rozmaitych rodzajów rzeczy czy zdarzeń i w konsekwencji - istnienie mniej lub bardziej określonych empirycznych prawidłowości, które charakteryzują każdy taki rodzaj i które odróżniają jeden rodzaj od innych" 52 .

Po tych wyjaśnieniach, dotyczących pojmowania w niniejszym studium przedmiotu formalnego historii, pozostaje jeszcze poruszyć jedną, bardziej specjalną słabą stronę tezy Maritaina o braku charakteru naukowego historii.

Jeżeli ten autor sądzi, że ze stanowiska perypatetyczno-tomistycznej teorii nauki [w sensie ścisłym] można uważać doktrynę o temperamentach, charakterologię, grafologię itd. za nauki ${ }^{53}$, to również mógłby na gruncie tej samej teorii nauki przyznać cechę naukowości historii. Przy takiej jej waloryzacji narzucałaby się jednak myśl, że element jednostkowy dziejów jako taki może być przedmiotem poznania naukowego. Twierdzenie, że ten element jednostkowy byłby ujmowany pośrednio,

50 Dz. cyt., 472.

51 Tamże, 470.

52 Tamże, 1. c. Jako uzasadnienie przytoczonych twierdzeń Nagela może stanowić jego analiza powodów, dla których Elżbieta I wstępując na tron brytyjski „etceterowała się" w oficjalnym, nie skróconym tytule (s. 473-483).

Zob. w przedmiocie sporu o idiograficzność historii: Władysław Tatarkiewicz, Nauki nomologiczne a typologiczne, ,Sprawozdania z czynności i posiedzeń Polskiej Akademii Umiejętności", 46 (1945, nr 1-5/30-31), to samo w: Skupienie $i$ marzenie, Kraków 1951, 129-130); Adam Schaff, Obiektywny charakter praw historii $Z$ zagadnień marksistowskiej metodologii historiografii, Warszawa 1955, 86-129; I. Lazari-Pawłowska, Idiograficzna koncepcja historii, „Studia Flozoficzne”, (1958, nr 1) 14-41; Andrzej Malewski, Zagadnienie idiograficzności historii, "Kwartalnik Historyczny", 65 (1958) 464-479; Swieżawski, Konieczność i wolność w dziejach, „Zeszyty Naukowe KUL”, 7 (1964, nr 4) 4-8; id., Zagadnienie historii filozofii, 62-76; Jerzy Topolski, Metodologia historii, Warszawa 1968, 457-459.

53 Zob. w przyp. 24 bliższe wyjaśnienia dotyczące stanowiska Maritaina w tej kwestii. 
poprzez pojęcia odnoszące się do tendencji rozwojowych dziejów i cech charakterystycznych danej epoki, brzmi mało przekonywująco.

Okazuje się więc, że, w przypadku większej konsekwencji, mógłby Maritain, nawet przy podzielanej przez siebie teorii nauki doskonałej, posunąć się dalej niż ks. de Tonquédec, który odmówił naukowości historii wziętej - jak się wyraził - w sensie najbardziej ścisłym ${ }^{54}$, ale przyznał charakter właściwego poznania naukowego ujęciu ogólnych praw dziejów ludzkich. Większa konsekwencja mogłaby ponadto doprowadzić francuskiego tomistę do porzucenia Arystotelesowskiej teorii nauki wyidealizowanej, jako teorii nie pozwalającej objąc wszystkich faktycznie uprawianych współcześnie nauk.

2. Nie mogąc podzielać zdania Maritaina, że historia nie jest nauką, przyznamy mu jednak część słuszności, gdy - w kontekście swego negatywnego stanowiska - usiłuje on ustalić specyficzny charakter prawdy historycznej nawiązując do pracy Marrou De la connaissance historique.

Wediug wymienionego tu profesora Sorbony prawda historyczna jest tak przynajmniej twierdzi Maritain ${ }^{55}$ - całkowicie różna od prawdy naukowej. Ona jest zgodnością z bytem, ale jej dowód nie daje się nigdy w pełni przeprowadzić z racji nieskończoności elementów, które należałoby uwzględnić. Ta prawda ma swoją obiektywność, ale jest to szczególny rodzaj obiektywności, do której osiągnięcia potrzeba zaangażowania się całego badacza ${ }^{56}$.

Maritain sądzi, że jest, być może, trochę kantyzmu w ujęciu Marrou ${ }^{57}$, niemniej jednak uważa je zasadniczo za odpowiadające stanowi faktycznemu. Ponieważ przy uprawianiu historii nie chodzi o wyodrębnianie istot abstrakcyjnych $\mathrm{w}$ obrębie tego, co ma charakter jednostkowy, ale o wskazanie tych jego aspektów, które są szczególnie ważne, dlatego to,

54 Zob. w niniejszym paragrafie wyjaśnienia w cz. II, przy jej końcu.

55 On the Philosophy of History, 6 (Pour une philosophie de l'histoire, 20-21).

56 Zob. w książce Marrou roz. IX: La vérité de l'histoire.

Ujęcie tego autora Maritain niewątpliwie przejaskrawił, przypisując mu zdanie o całkowitej odrębności prawdy historycznej od prawdy naukowej. W rzeczywistości Marrou podkreśla na początku wskazanego rozdziału (s. 223), że prawda historyczna nie jest i nie może być całkiem innego porządku (d'un tout autre ordre) $\mathrm{w}$ porównaniu z prawdą z zakresu nauk przyrodniczych, skoro, jak pisze: "la raison humaine est une, si diverses que soient ses applications, si souple que soit son comportement: un logicien ne découvre pas de fossé infranchissable entre les opérations mentales du physicien, du naturaliste, et celles de l'historien" (1. c.).

57 Marrou odpowiedział Maritainowi: „Je ne m'étais référé qu’à un Kantisme très exotérique dont il est permis de penser, avec K. Jaspers ( $\mathrm{Ka} F$ Fi philosophique, tr. fr., Paris 1953, p. 12), qu'il est intégré à la philosophia perennis; cf. les remarques de R. Marlé (Recherches de science religieuse, 1958, p. 428 et n. 15) au sujet des critiques que $R$. Bultmann a formulées à l'égard de ma référence à l'objet "nouménal», dans les additions (pp. 134, n. 2; 135, n. 1; 159, n. 1) de l'édition allemande des Gifford Lectures de 1955 (Geschichte und Eschatologie, Tübingen, 1958)" (Dz. cyt., 297, przyp. 17). 
na co zwraca uwagę historyk, jest - zdaniem francuskiego tomisty decydujące dla wyników badań. Kierunek uwagi jest znów - według niego - funkcją dyspozycji intelektualnych historyka, jego filozofii człowieka, jego oszacowania różnych form aktywności ludzkiej i ich względnego znaczenia, a także oceny wartości moralnych, politycznych, religijnych, technicznych i artystycznych. Stąd też prawda historyczna jest dla Maritaina prawdą faktycz $\mathrm{nac}$, a nie prawdą rozumow ą (the truth factual, not rational truth). Określając prawdę historyczną w sposób zbliżony w pewnej mierze do ujęcia prawd faktycznych przez Gotfryda W. Leibniza ${ }^{58}$, chce Maritain powiedzieć, że choć prawda historyczna daje się w wielu przypadkach poznać w sposób pewny, a nie tylko koniekturalny, to jednak nigdy nie daje się dowieść w sposób ścisły, ani też nikomu nie narzuca się bezwzględnie ${ }^{59}$.

W tych wywodach Maritaina jedno nie może podlegać wątpliwości, że prawda historyczna posiada szereg takich uwarunkowań doktrynalnych, jakich nie posiada prawda w obrębie nauk przyrodniczych. Składają się na nie różne u różnych historyków tezy z zakresu filozofii człowieka, etyki filozoficznej, filozofii religii, filozofii kultury, sztuki, itd. Ale te uwarunkowania doktrynalne wnoszą do prawdy historycznej w porównaniu z prawdą z dziedziny nauk przyrodniczych jedynie różnicę s to p nia, różnicę ilościow ą, gdyż w tych drugich naukach zdania, które dotyczą zjawisk dokonujących się w przyrodzie, są również funkcją określonych teorii. Nie można więc utrzymywać, że prawda historyczna jest całkowicie różna od prawdy, do jakiej dochodzi się na terenie nauk przyrodniczych ${ }^{60}$.

58 Zob.: Nowe rozważania dotyczace rozumu ludzkiego, tłum. z oryginału franc. Izydora Dąmbska, [bmw] 1955, t. I, 53, t. II, 150; Zasady filozofii, czyli monadologia, tłum. Stanisław Cichowicz, w: Wyznanie wiary filozofa - Rozprawa metafizyczna - Monadologia - Zasady natury i łaski oraz inne pisma filozoficzne, przełożyli Cichowicz, Juliusz Domański, Henryk Krzeczkowski, Henryk Moese, [bmw] 1969, 303-304 (§ 33, 36-37). $21-22)$.

59 On the Philosophy of History, 7-8 (Pour une philosophie de l'histoire, ${ }_{60}$ K. Riezler, The Historian and Truth, „The Journal of Philosophy”, 45 (1948) n. 14; H. M. Lynd, The Nature of Historical Objectivity, tamże, 47 (1950) n. 2; Nicola Petruzzellis, Le esigenze della verità nella storia, „Doctor Communis”, 5 (1952, n. 3) 265-282; Fritz Kaufmann, Reality and Truth in History, w: Perspectives in Philosophy, Essais by Members of the Department of Philosophy [of the Ohio State University]. Sponsored by the Gluck Fund in memory of Gizella Ginzler Roth. Columbus. The Ohio State University, 1953, 43-54; Paul Ricoeur, Histoire et vérité, Paris 1955; L. Althusser, Essais et propos sur l'objectivité de l'histoire (lettre à Paul Ricoeur), „Rev. Enseignement Philosophique”, 5 (1955, n. 4) 3-15; J. Muglioni, L'histoire et vérité, ,Revue Socialiste”, (1955, n. 90) 312-321; Christopher Blake, Can History be Objective?, „Mind”, 64 (1955) 61-78; Harold N. Lee, Knowledge and Truth in Historical Inquiry, w: "Tulane Studies in Philosophy", 5 (1956) Virgil Hinshaw, The Objectivity of History, "Philosophy of Science" (Baltimore), 25 (1958) 51-58; R. Wittram, Wahrheit in der Geschichte, „Deutsche Universitätszeitung", 13 (1958, n. 7) 390-399; Walter D. Love, Truth in History, w: Truth, Myth, and Symbol, edited by Thomas J. J. Altizer, William A. Beardslee, 
Wchodząc w polemikę bardziej szczegółową trzeba zauważyć, że jeżeli prawda historyczna daje się - według Maritaina - poznać w wielu przypadkach w sposób pewny, to daje się również w tych przypadkach ściśle dowieść, uzasadnić. Ścisły dowód byłby niemożliwy jedynie wtedy, gdyby słusznym okazało się założenie infinitystycznej teorii rzeczywistości, jaką podzielał Leibniz. Ale w przypadku słuszności takiego założenia o żadnej prawdzie historycznej nie można by mówić w sposób zasadny, że zdobyliśmy o niej poznanie pewne. Skoro Maritain nie podziela infinityzmu Leibnizowskiego, dlatego "nie ma podstaw do wyodrębniania prawdy faktycznej od prawdy rozumowej. Podjęcie tego rozróżnienia w tomiźmie jest wyrazem synkretyzmu, a nie twórczej asymilacji.

3. Maritain ma niewątpliwie rację, gdy twierdzi, że filozofia historii nie jest częścią metafizyki, a tylko ją zakłada (razem z filozofią przyrody), skoro przedmiotem badań filozofii historii są czyny ludzkie, wzięte $\mathrm{w}$ ich urzeczywistnianiu się $\mathrm{w}$ toku ewolucji ludzkości. Czy wobec tego włączymy bez reszty filozofię historii do filozofii moralnej, jak to czyni Maritain?

Wydaje się, że takie włączanie jest ujęciem jednostronnym, gdyż wymienione czyny rozpatruje się $\mathrm{w}$ filozofii historii nie tylko w aspekcie wartości etycznych, ale również pod kątem widzenia wartości technicznych, artystycznych, religijnych i politycznych. Za Stefanem Swieżawskim ${ }^{61}$ trzeba więc powiedzieć, że filozofia historiinie jest działem samej tylkofilozofii moralnej, etyki, ale działem całejantropologii filozoficznej, a w szczególności filozofii ludzkiego działania, jeżeli to działanie będzie pojmowało się za Arystotelesem tak szeroko, ,że obejmuje ono nie tylko postępowanie (kierowane cnotą roztropności), ale także wytwarzanie (kierowane cnotą «sztuki»), a nawet ,sposób funkcjonowania naszego intelektu" 62. Niewątpliwie jest miejsce w obrębie antropo-

J. Harvey Young. Englewood Cliffs (N. J.), Prentice-Hall, 1962, 35-50; H. D. Lewis, Can History be Objective?, „Int. Philos. Quart.”, 2 (1962) 219-243; Chaïm Perelman, Objectivité et intelligibilité dans la connaissance historique, w: Raisonnement et démarches de l'historien, publié par Chaïm Perelman. Extrait de la „Revue de l'Institut de Sociologie". Bruxelles, Éditions de l'Institut de Sociologie, Université Libre de Bruxelles, 1963, 141-151; Swieżawski, Zagadnienie historii filozofii, 211-241; R. Lutman, Zagadnienie prawdy w historii, w: M. H. Serejski (red.), Historycy o historii, Warszawa 1966, t. 2; Raymond Aron, Introduction à la philosophie de l'histoire - Essai sur les limites de l'objectivité historique, [bmw] 1967, 333-437; id., La philosophie critique de l'histoire, [bmw] 1969, passim, w szczególności s. 217-268, 281-291; Topolski, dz. cyt., 235-240; Schaff, Historia i prawda, Warszawa 1970, 288-323.

61 Dz. cyt., 459-460.

62 Por. jeszcze Swieżawskiego: Zbieżności metafizyki realistycznej i historiografii, w: Szkice Filozoficzne - Romanowi Ingardenowi w darze, Kraków 1964, 280; Konieczność i wolność w dziejach, 8-9. 
logii filozoficznej na filozofię historii, gdyż — jak zauważa Swieżawski ${ }^{63}$ - człowiek ma nie tylko określoną naturę, ale również historię. Należy zatem Maritainową teorię filozofii historii poszerzyć z ujęcia filozoficzno-etycznego w ujęcie filozoficzno-antropologiczne.

W przedmiocie włączania przez Maritaina filozofii historii do filozofii moralnej musimy wysunąc jeszcze jedno zastrzeżenie. Mianowicie nie możemy wiązać filozofii historiiz podzielaną przez Maritaina filozofiac moralna adekwatnie wziętą.

Jeżeli francuski tomista postępuje inaczej, to czyni tak dlatego, że, zatracając $\mathrm{w}$ pewnym zakresie poczucie metodologicznej odrębności przedmiotu materialnego $\mathrm{i}$ formalnego náuki, dowolnie $\mathrm{zakłada}$, i $\dot{z}$ filozofia historii powinna pod każdym względem zrównać sięze swym przedmiotem. Możemy nawet posunąć się dalej i powiedzieć, że Maritain oparł się na założeniu w sposób oczywisty błędnym, iż do tego, by można było o czymś wypowiedzieć twierdzenie prawdziwe, musi się uwzględnić wszystko, co jest w jego przedmiocie pod jakimkolwiek względem do poznania. Maritain jakoś nie liczy się z tym, że prawdziwość naszego poznania daje się pogodzić z jego aspektowością.

Założenie przyjęte przez autora On the Philosophy of History jest także wyrazem ni ek ons ekw enc ji. Bo jeżeli, jak on czyni ${ }^{64}$, utrzymuje się, że filozofia historii posługuje się metodą filozoficzną, to w takim razie jej ujęcie może dotyczyć tego tylko, co daje się dosięgnąć wymienioną metodą. Nie może więc dotyczyć danych zapożyczonych od teologii, w stosunku do których metoda filozofii historii jest nieadekwatna.

W następstwie przyjętego przez siebie założenia Maritain nie zdołał dowieść specyficznejodrębności swej filozofii historii od teologii historii. Jego filozofia historii obejmuje zasadniczo tę samą problematykę co teologia historii (rozwój świata, królestwo Boże w stanie pielgrzymowania). Od tej drugiej nauki różni się tym tylko, że przedmiotem jej głównego zainteresowania jest nie królestwo Boże i historia zbawienia, ale rozwój świata. Jest to więc odrębność, która może dzielić ubocznie badaczy uprawiających tę samą naukę. Taka odrębność czysto akcydentalna nie może stanowić o specyficznej odrębności epistemologicznej i metodologicznej uprawianej przez Maritaina chrześcijańskiej filozofii historii. Ta dyscyplina jest $\mathrm{w}$ gruncie rzeczy teologią historii. Wszak nawet termin ,świat" nie posiada w ujęciu francuskiego tomisty treści czysto filozoficznej. Termin ten

63 Zagadnienie historii filozofii, 459,

64 On the Philosophy of History, 40 (Pour une philosophie de l'histoire, 53). 
bowiem oznacza u niego - jak już wiemy ${ }^{65}$ - nie tylko kosmos filozofii greckiej, ale również hic mundus Ewangelii, a więc świat rozpatrywany w interpretacji charakterystycznej dla chrystianizmu.

Okazuje się, że w ramach nauk filozoficznych nie ma miejsca na chrześcijańską filozofię historii, wziętą w rozumieniu przedstawionym przez Maritaina, a więc $w$ sensie teoretyczno-normatywnym. Jeżeli będzie się chciało być filozofem - filozofem autentycznym, a nie więcej lub mniej filozofującym teologiem - będzie się uprawiało filozofię historii, która może być przyjętą przez jednostki o rozmaitym światopoglądzie religijnym, a nawet przez jednostki nie wyznające żadnej religii. Jest rzeczą dostatecznie widoczną, że nazywanie takiej filozofii historii chrześcijańską byłoby czymś bezprzedmiotowym.

4. Poszerzenie teorii filozofii historii $\mathrm{z}$ ujęcia filozoficzno-etycznego w ujęcie filozoficzno-antropologiczne nie przekreśla jeszcze samo przez się twierdzenia Maritaina o przynależności filozofii historii do filozofii praktycznej. Są jednak powody, które skłaniają nas do porzucenia tego twierdzenia.

Gdy w tradycji arystotelesowsko-tomistycznej uważano za praktyczne te nauki filozoficzne, w których poznanie jest podejmowane dla działania ${ }^{66}$, nie liczono się z pewnym rozróżnieniem, jakie narzuca się przy dokładniejszej analizie. Chodzi o rozróżnienie między poznaniem, które służy do be z pośredni e go kierowania określonym działaniem konkretnym, a poznaniem dotyczącym pewnego typu działania, nie przyporządkowanym bezpośrednio żadnej jego konkretnej postaci, mającym za cały cel stwierdzanie i wyjaśnianie.

Pierwszą formę poznania należy — ze względu na jego zasadniczą

65 Zob. przyp. 40.

66 Zob. Klasyczne teksty św. Tomasza z Akwinu: Expositio super Boetium de Trinitate, qu. V, a. 1 (Opuscula omnia, cura et studio Petri Mandonnet OP, Parisiis 1927, t. III, 99;) In Metaphysicam Aristotelis commentaria, cura et studio M. R. Cathala OP, Taurini 1926, lib. I, lect. I, n. 32-33, s. 12-13, lib. II, lect. II, n. 289-291, s. 101-102, lib. XI, lect. VII, n. 2265, s. 644; In Aristotelis librum De anima commentarium, cura ac studio Angeli M. Pirotta OP, Taurini 1925, lib. I, lect. I, n. 3, s. 4, lib. III, lect. XV, n. 820-821, s. 267; Sum. theol. I, qu. I, a. 4, qu. XIV, a. 16; In decem libros Ethicorum Aristotelis ad Nicomachum expositio, cura ac studio A. M. Pirotta, Taurini 1934, lib. I, lect. I, n. 8, s. 4, lect. II, n. 24, s. 8 , lect. III, n. 40 , s. 13 , lib. II, lect. II, n. $255-256$, s. $88-89$, lib. X, lect. XIV, n. 2138 , s. $679-680$.

Por. współczesne rozwinięcia ujęcia tradycyjnego u Maritaina w Les degrés du savoir, 901-918, i u Yves Simona w Critique de la connaissance morale, Paris 1934, 7-37.

Terminem „działanie”, jakim posłużyłem się wyżej, w zasadniczym tekście, obejmuję to, co we współczesnej polskiej literaturze filozoficznej bywa określane, w sposób zresztą niejednoznaczny, jako c z y n ność i d zi ałanie. Zob.: Czesław Znamierowski, Oceny i normy, Warszawa 1957, 419-420; Mieczysław Kreutz, Próba zdefiniowania terminu „czynność”, „Przegląd Psychologiczny”, 16 (19) 26-71. (Krytyka definicji czynności, jaką przedstawił Tadeusz Tomaszewski w roz. III Wstępu do psychologii, Warszawa 1963). 
dominantę - nazwać poznaniem praktyc znym, mimo że zawiera ono wyraźnie i domyślnie szereg teoretycznych elementów treściowych. Natomiast druga forma poznania ni e róż i się pod względem swego ostatecznego celu od poznania uznawanego tradycyjnie za teoretyczne ${ }^{67}$. Chodzi w nim przecież o poznanie dla samej prawdy, mimo że zawiera ono implikacje praktyczne w tym sensie, że obejmuje zasady, którymi dana jednostka powinna się posługiwać w ramach poznania służącego jej do bezpośredniego pokierowania konkretnym działaniem ${ }^{68}$. Nazwanie analizowanego poznania spekulatywno-praktycznym - ma to miejsce u Maritaina ${ }^{69}$ i Yves Simona ${ }^{70}$ jest wyrazem zdania sobie do pewnego stopnia sprawy z przedstawionego tu stanu rzeczy, niemniej jednak jest to ujęcie kompromisowe, które zasadniczo nie wykracza poza tradycyjnie ujmowaną charakterystykę epistemologiczną, idącą po linii mieszania celu nauki o danym typie działania z celem poznania przyporządkowanego bezpośrednio u danej jednostki jej konkretnemu działaniu, tego mieszania, jakiego wyrazem jest twierdzenie Akwinaty: finis [...] scientiae [moralis] non est manifestatio veritatis, sed bonum operis ${ }^{71}$.

Okazuje się więc, że w odniesieniu do działania, a więc i w odniesieniu do działania etycznego, należy wyodrębnić nie tylko poznanie praktyczne, ale również i poznanie teoretyczne. Jednakowoż p o znani e praktyczne nie ma charakteru naukowego, gdyż jest to poznanie, w którym tylko dana jednostka jest zainteresowana w określonej sytuacji konkretnej. Nie może więc to poznanie wchodzić w obręb poznania filozoficznego, dotyczącego treści o powszechnej wartości. P oznaniem naukowym i filozoficznym działania moze być wyłącznie jego poznanie teoretyczne, które z poznaniem praktycznym wykazuje wyraźną nieciągłość z epistemologicznego punktu widzenia.

Ks. Van Steenberghen ${ }^{72}$ i Jerzy Kalinowski 73 słusznie odrzucają ciągle jeszcze podejmowany niemal przez wszystkich tomistów podział filozofii na teoretyczną i praktyczną. Razem z wymienionymi autorami

67 Zob. w przedmiocie tego poznania teksty św. Tomasza z Akwinu cytowane w przyp. 66 .

68 Możemy tu wykorzystać to, co św. Tomasz z Akwinu pisał w Sum. theol., I, qu. XIV, a. 16, że o tym, co może być przedmiotem działania, jest możliwa nauka teoretyczna pod względem jej celu, a także quantum ad modum sciendi.

69 Dz. cyt., $618-621,901-905$.

70 Dz. cyt., $80-97$.

71 In decem libros Ethicorum Aristotelis ad Nicomachum expositio, lib. II, lect. IX, n. 351 , s. 121. Por. identyczną w zasadzie wypowiedź $w$ lib. I, lect. III, n. 40 , s. 13 , i w lib. II, lect. II, n. 256, s. 88-89, lect. XI, n. 369, s. 128, lib. X, lect. XIV, n. 2138 , s. $679-680$.

72 Réflexions sur la systématisation philosophique, „Revue Néo-Scolastique de Philosophie", 41 (1938) 209; Épistémologie, 256.

73 Art. cyt., 113-114. 
powiemy, że całą filozofię, nawet gdy ona dotyczy działania, należy uznać za teoretyczną. Nie możemy więc podjąc tezy Maritaina o przynależności filozofii historii do filozofii praktycznej, gdyż ta teza jest po prostu bezprzedmiotowa.

\section{$\S$ 2. PRAWA HISTORII W UJĘCIU MARITAINA.}

Głównym celem, do którego zmierzał francuski tomista w analizowanej przez nas książce, było wskazanie praw dziejów ludzkich. Zagadnienia istnienia i natury tych praw bliżej nie przebadał na gruncie podzielanej przez siebie teorii historii i $\mathrm{w}$ łączności z odnośną literaturą naukową ${ }^{74}$. Zaznaczył tylko bardzo ramowo, że prawa historii mają to być prawa, które oświetlają historię ludzką i czynią ją bardziej zroz u mi a $ł a ̨$, ale które jej ni e $\nmid \nmid u m$ a c zą, ani nie poddają biegu wydarzeń konieczności. Maritain bowiem sądzi, że koniecznymi we wskazanej historii są tylko pewne rysy ogólne i pewne podstawowe konfiguracje, w obrębie których do woli ludzkiej należy określenie szczegółowej orientacji 75 .

Wśród praw historii wyróżnił formuły aksjomatyczne albo prawa funkcjonalne i formuly typologiczne albo prawa wektorialne. Rozpotrzymy je kolejno. Do niektórych $\mathrm{z}$ nich znajdziemy sporo uwag również w dawniejszych pracach Maritaina.

FORMUEY AKSJOMATYCZNE ALBO PRAWA FUNKCJONALNE.

Należą do nich - według Maritaina - prawa rozwoju historycznego, rozważanego bądź w swym całokształcie bądź w którejś jego części. Wy-

74 Zob. m. in.: B. Wolman, Historical Laws - do they exist?, w: Proceedings of the tenth International Congress of Philosophy (Amsterdam, August 11-18, 1948), edited by E. W. Beth, H. J. Pos and J. H. A. Hollak, Amsterdam 1949, vol. I, fasc. II, 960-963; Adam Schaff, Obiektywny charakter praw historii, Warszawa 1955; Joseph Vogt, Gesetz und Handlungsfreiheit in der Geschichte - Studien zur historischen Wiederholung, Stuttgart 1956; H. Eowmiański, $\mathrm{Na}$ marginesie zagadnienia praw historii, „Myśl Filozoficzna”, 4 (1956) 160-169; William Dray, Laws and Explanation in History, London - Oxford 1957; Oscar Halecki, The Moral Laws of History, ,The Catholic Historical Review" (Washington), 42 (1957) 409-440; Alfred Stern, Historical Laws and Natural Laws, "Main Currents in Modern Thought", 18 (1961, n. 2) 27-33; Carl G. Hempel, Aspects of Scientific Explanation and Other Essays in the Philosophy of Science, New York - London 1965, 231-243 (rozdz. 9: The Function of General Laws in History); A. J. Gurewitsch, Algemeines Gesetz und konkrete Gesetzmässigkeit in der Geschichte, Uebers. von H. Schulze, „Sowjetwissenschaft, Gesellschaftswissenschaftliche Beiträge”, Berlin, 1966, 177-193.

75 On the Philosophy of History, 165; por. 31-32 (Pour une philosophie de l'histoire, 173; por. 44-45). 
rażają one relację funkcjonalną między pewnymi ogólnymi i dającymi się zrozumieć cechami procesu dziejowego.

1. Jako pierwsze $z$ tych praw Maritain wyodrębnił prawo podwójnego postępu antagonistycznego ${ }^{76}$.

Według tego prawa historia ma podążá równocześnie w kierunku wzrostu dobra i zła. Z religijnego punktu widzenia chodzi przy tym prawie o dwie, krzyżujące się ze sobą w każdym momencie dziejów ludzkich, dążności, z których jedna prowadzi do zbawienia, a druga na wieczne zatracenie. W aspekcie filozoficznym wskazane prawo daje się określić jako prawo degradacji i równoczesnego ożywienia energii historii (the law of the degradation, on the one hand, and the revitalization, on the other, of the energy of history). Jest bowiem - zdaniem Maritaina - tak, że upływ czasu i pasywność materii pociągają za sobą w sposób naturalny rozpraszanie i degradację energii $\mathrm{w}$ świecie pozaludzkim i w obrębie dziejów ludzkich, z drugiej znów strony jakość tej energii stale się zwiększa dzięki właściwym duchowi i wolności siłom twórczym, które normalnie ujawniają się w wysiłku i ofierze pewnych jednostek. W niektórych okresach historii przeważa dążność do degradacji, w innych znów dążność w kierunku postępu. W każdym jednak czasie te dwie dążności współistnieją ze sobą w jakimś stopniu.

Jak widzimy, Maritain jest daleki od negowania wszelkiego postępu $\mathrm{w}$ dziejach ludzkich, ale postęp, jaki w nich dostrzega, nie jest postępem koniecznym, prostolinijnym i nieskończonym, jaki zakładano w XVIII w. i jaki ze strony tomistycznej przyjmował ks. Michalski, nazywając jego ujęcie perfekcjoryzmem ${ }^{77}$. Zdaniem francuskiego tomisty najbardziej uderzające zastosowanie omawianego prawa miało miejsce przy przejściu ludzkości ze stanu dziecięctwa do stanu dojrzałości.

Szczególnym przypadkiem tego prawa jest praw o, we dłu g k tórego błąd, mimo że jest pasożytem przy procesie zdobywania prawdy, odgrywa rolę pozytywną w postępie poznania teoretycznego, w szczególności poznania przyrodniczego i. filozoficznego ${ }^{78}$.

Maritain sądzi, że do wielkich odkryé naukowych dochodzi zwykle dzięki bodźcom, które mają źródło w jakimś błędzie teoretycznym. I tak, matematyczne poznanie przyrody, zapoczątkowane w XVI i XVII w.,

76 On the Philosophy of History, 43-50 (Pour une philosophie de l'histoire, $57-64)$.

77 Tomizm wobec wspótczesnej filozofii dziejów, w: Magister Thomas Doctor communis, 23-24, 27.

Idei perfekcjoryzmu ks. Michalski dopatrywał się u św. Tomasza z Akwinu w Sum. theol., I-II, qu. XCVII, a. 1. $64-65)$.

78 On the Philosophy of History, 51-52 (Pour une philosophie de l'histoire, 
znajdywało wzmacniającą je podnietę w błędnej, pasożytującej na nim filozofii mechanistycznej, która zdawała się być przez długi czas nieodłączna od niego ${ }^{79}$. Podobnie, do uświadomienia tego, że nauki przyrodnicze są poznaniem zjawisk, poznaniem odrębnym od filozofii pojętej jako poznanie bytu dostępnego wyłącznie dla umysłu, dokonało się w tym samym czasie co „rewolucja kopernikańska”, dokonana przez Emanuela Kanta. Można by powiedzieć, że to dzięki błędom wymienionego filozofa zostało przyjęte nowożytne pojęcie nauk przyrodniczych, rozumianych jako poznanie zjawisk ${ }^{80}$. Tak samo wielkie odkrycia psychologiczne w przedmiocie nieświadomości znalazły wzmocnienie i dodatkowy bodziec w błędnej filozofii życia, jaką podzielał Zygmunt Freud ${ }^{81}$.

2. Konsekwencją prawa podwójnego postępu antagonistycznego jest według Maritaina - prawo ambiwalencji historii pod względem wartości jej osiągnięć ${ }^{82}$.

Jeżeli w każdym momencie dziejów ludzkich występują przeciwstawne sobie dążności, to - jak sądzi autor On the Philosophy of History żaden okres owych dziejów nie może spotkać się ani $z$ bezwzględnym potępieniem, ani $z$ bezwzględną aprobatą. „Byłoby równie rzeczą mało rozsądną potępiać [bez reszty] wieki średnie z punktu widzenia racjonalistycznego (from the rationalist point of view), jak potępiać [całkowicie] czasy nowożytne z punktu widzenia rzekomo chrześcijańskiego" 83. Ambiwalencja historii w podanym sensie daje się stwierdzić w rozwoju cesarstwa rzymskiego, we wzajemnych stosunkach Kościoła i państwa w okresie po Konstantynie Wielkim, w różnych fazach rewolucji przemysłowej, a także w obecnym władztwie nauki fizyko-matematycznej i technologii. Dziś szczególnie dobitny przykład omawianej ambiwalencji stanowi nadejście ery atomowej $\mathrm{z}$ możliwościami, jakie przynosi dla zniszczenia ludzkości, jak i dla niesłychanego poprawienia jej egzystencji.

79 Por. Maritaina: La philosophie de la nature - Essai critique sur ses frontières et son objet, 39-40; Science et sagesse, 82-83.

80 Por. Maritaina: La philosophie de la nature..., 42-43; Science et sagesse, 84.

81 Por. Maritaina: Les degrés du savoir, 292 (przyp.); Quatre essais sur l'esprit dans sa condition charnelle, 17-56.

82 On the Philosophy of History, 52-59 (Pour une philosophie de l'histoire, $65-72)$.

Por. jeszcze Maritaina: Religion et culture, Paris 1930, 31-34; Du régime temporel et de la liberté, Paris $1933^{2}, 100-102$.

83 Oto, w jaki sposób ocenia Maritain czasy nowożytne: „There were, to be sure, great spiritual errors in modern times: but great truths were also discovered, which deal with the order of nature and natural reason, and are of importance for the spirit. The Rousseauist errors which, especially in Europe, preyed upon the democratic principle, and the false philosophies with which it was often confused by accident, and which are corroding it from within, ask for a purification of this principle; but they also ask for a deeper recognition of its intrinsic truth, as well as of its vital connection with Gospel inspiration. The hope of mankind as to its temporal life is inseparably tied up with the advent of democratic philosophy in modern times". On the Philosophy of History, 52-53. 
3. Dalszym prawem funkcjonalnym historii jest - dla Maritaina prawo „owocowania" historycznego dobra i zła ${ }^{84}$. Dotyczy ono związku zachodzącego między moralnością i polityką. Maritain zajął się nim dość szczegółowo w studium The End of Machiavellianism ${ }^{85}$, zamieszczonym później w wersji francuskiej w książce Principes d'une politique humaniste ${ }^{86}$.

Zdaniem francuskiego tomisty dobro doczesne, w którym „owocuje” sprawiedliwość społeczeństw ludzkich, i zło doczesne, w którym „owocuje" ich niesprawiedliwość, nie mają nic wspólnego z rezultatem bezpośrednio dostrzegalnym względnie z rezultatem, który umysł ludzki mógł przewidzieć. $\mathrm{Na}$ realizację jednego i drugiego potrzeba trwania historycznego, które wykracza poza czas życia poszczególnych generacji. Niemniej jednak jest tak, że $-z$ racji podlegania społeczeństw ludzkich porządkowi moralnemu - sprawiedliwość i prawość dążą s ame przez siebie do zachowania tych społeczeństw i do ich realnego sukcesu, zaś niesprawiedliwość i zło dążą również s a m e przez s i e bi e do zniszczenia owych społeczeństw i do ich klęski. Są to jednak procesy długofalowe.

Maritain podkreśla jeszcze, że gdy idzie o sprawiedliwość i cnoty moralne, to one nie obalają praw naturalnych starzenia się społeczeństw ludzkich, ani nie chronią przed zniszczeniem ze strony czynników fizycznych. Tak jest dlatego, bo społeczności ludzkie, narody, państwa, cywilizacje i wszystkie kolektywy niezdolne do nieśmiertelności należą nie tylko do porządku moralnego, ale również do porządku fizycznego ${ }^{87}$.

84 Tamże, 59-62 (Pour une philosophie de l'histoire, 72-75).

85 ,Review of Politics”, Notre Dame, Indiana, 4 (1942) 1-33.

W Iormie skróconej Maritain przedstawił swoje uwagi na sympozjum poświęconym zagadnieniu miejsca etyki w naukach społecznych, które to sympozjum odbyło się w dniu 26 IX 1941 r. z ckazji uroczystości 50-lecia uniwersytetu w Chicago. Tłumaczenie franc. wskazanego studium pt. La fin du machiavélisme ukazało się w „Nova et Vetera", (1942) 113-145.

86 New York 1944, 171-232; Paris 1945, 151-206. - Tekst franc. opiera się na tłumaczeniu, które ukazało się w „Nova et Vetera”. Maritain wprowadził do niego dwa kilkuwierszowe dodatki.

Zob. jeszcze tego autora - poza Principes d'une politique humaniste L'homme et l'état, tlum. $\mathrm{z}$ oryginału ang. [Man and the State, Chicago 1921] Robert i France Davril, Paris 1953, 50-52, 54-55.

${ }_{87}$ "Je ne dis pas - pisze Maritain - qu'une politique juste réussira toujours en fait, même dans un avenir éloigné, ni que le machiavélisme échouera toujors en fait, même dans un avenir éloigné. Car avec les nations, les États et les civilisations, nous sommes dans l'ordre de la nature, où la mortalité est naturelle et où la vie et la mort dépendent de calises physiques autant que de causes morales. Mais je dis que la justice travaille, pour sa causalité propre, dans le sens de la prospérité et du succès pour l'avenir, comme une bonne sève travaille en vue du fruit parfait; et que le machiavélisme, par sa causalité propre, travaille pour la ruine et la banqueroute, comme le poison dans la sève travaille pour la maladie et la mort de l'arbre". Principes d'une politique humaniste, 176. Niemal to samo w L'homme et l'état, 51. 
4. Z kolei Maritain wyodrębnia prawo świ t towego znaczenia wydarzeń o doniosłości historycznej88.

Jego działanie uwidacznia się wówczas, gdy w czasie dostatecznie długim wytworzyła się wśród pewnych narodów, niezależnie od form organizacji politycznej, witalna jedność, na którą składa się wspólnota doświadczenia historycznego, nadziei i cierpienia oraz wspólnota struktur duchowych i kulturalnych. Gdy w przypadku zaistnienia takiej jedności dokcna się $\mathrm{w}$ jakimś jednym narodzie wydarzenie o doniosłości historycznej, stanowiące konieczne pod pewnym względem zaktualizowanie potencjalności i aspiracji wiekowych, wówczas to wydarzenie - twierdzi Maritain - dokonuje się nie tylko dla tego narodu, ale również d la wszystkich narodów, które są związane ową jednością. Dokonuje się dla tych narodów $w$ tym znaczeniu, że one są zmuszone do zasymilizowania jego treści ideologicznej i do odpowiedniego przekształcenia własnych tradycji i struktur.

Ale, wraz ze swym dopełnieniem się, to zdarzenie posiadające wagę historyczną ,wyczerpało, żeby tak powiedzieć, ilość energii twórczej, która była potrzebna do jego pojawienia się w historii ludzkiej”. „I jako czynnik odnowienia i działania historycznego zakończyło swoją rolę i należy już do przeszłości", ustępując miejsca nowym problemom i nowym zmianom o doniosłości historycznej, które z kolei wywołuje energia twórcza historii.

5. Dalszym prawem funkcjonalnym jest — według Maritaina - p r awo progresywnego wzrostu świadomości the law of progressive prise de conscience) ${ }^{89}$.

Prawo to wiąże się $z$ historią cywilizacji w ogólności, ale jego działanie w niej przejawia się w sposób niezwykle powolny i „wycinkowy”. I tak, gdy ujawnia się w jednej dziedzinie rozwoju duchowego, w drugiej można zupełnie nie dostrzegać jego obecności. W Grecji na przykład posiadano świadomość wolności politycznej obywatela, ale brak było świadomości wewnętrznej i duchowej wolności osoby ludzkiej w stosunku do państwa. W dziedzinie filozofii zdanie sobie sprawy z tego, że teoria poznania stanowi odrębną naukę, przyszło bardzo późno. Zapewne, że Arystateles i wszyscy wielcy filozofowie mieli swoją teorię poznania. Ale dopiero u Kanta stała się ona oddzielną nauką ${ }^{90}$. Sam Maritain uświadomił sobie stosunkowo późno jej epistemologiczną i metodologiczną odrębność. Początkowo traktował ją - podobnie jak $\mathrm{m}$. in. o. Reginald

83 On the Philosophy of History, 62-68 (Pour une philosophie de l'histoire, $75-81)$.

89 On the Philosophy of History, 69 (Pour une philosophie de l'histoire, 81-82). Por. jeszcze Maritaina Religion et culture, 30-31.

90 Maritain wyraża się o teorii poznania najpierw: a particular discipline, później: a special theory, a special discipline. 
Garrigou-Lagrange OP 91 i o. Józef Gredt 92 - jako część organiczną metafizyki, jako rodzaj apologetycznego wstępu do niej ${ }^{93}$.

6. Wykład praw funkcjonalnych historii kończy Maritain analizą praw dotyczących hierarchii środków do celów duchowych i doczesnych (społecznych lub politycznych) ${ }^{94}$. Prawa te są wyrazem odpowiedniości, narzucającej się nam w sposób bezpośrednio oczywisty, jaka powinna zachodzić między porządkiem środków a porządkiem celów.

Jako pierwsze z nich Maritain wymienia prawo wyżzości doczesnych środków ubogich nad doczesnymi środkami bogatymi przy dążeniu do celów duchow y c h.

Przez doczesne środki bogate (rich temporal means) francuski tomista rozumie te środki, które, będąc zaangażowane w ociężałość materii, domagają się $\mathrm{z}$ siebie, w jakimś zakresie, dotykalnego sukcesu. Srodkami doczesnymi ubogimi (humble temporal means, les moyens temporels pauvres ${ }^{95}$ ) są znów - według niego środki właściwe dla ducha. Do nich należy podjęcie krzyża $\mathrm{w}$ takim czy innym znaczeniu.

Maritain sądzi, że całkowite wyłączanie doczesnych środków bogatych byłoby czymś niedorzecznym, gdyż one stanowią część naturalnej osnowy życia ludzkiego. Nawet religia musi zgodzić się w jakiejś mierze na przyjęcie ich pomocy. Jednakowoż doczesne środki ubogie są — zdaniem francuskiego myśliciela - skuteczniejsze przy dążeniu do celów duchowych. Są one tym bardziej skuteczne, im są bardziej , lekkie” pod względem swej materii, im są bardziej wyrazem ogołocenia i są mniej dostrzegalne w porządku doczesnym. O ich skuteczności decyduje przysługująca im czystość.

D r u g i m prawem dotyczącym hierarchii środków jest — dla Maritaina - prawo wyższości duchowych środków docze-

91 De Revelatione, Romae 1931, t. I, 14.

92 Elementa philosophiae aristotelico-thomisticae, Friburgi Brisg. $1926^{4}$, t. I, 190 (n. 228) i t. II, 3.

${ }_{93}$ Réflexions sur l'intelligence et sur sa vie propre, Paris 1926 2, 11, 39; Les degrés du savoir, $154-155,430-431$.

W cyt. 7-ym wyd. głównego dzieła Maritaina zostały przedrukowane jego pierwotne poglądy na przynależność epistemologiczną i metodologiczną teorii poznania.

94 On the Philosophy of History, 70-75 (Pour une philosophie de l'histoire, $83-88)$.

Zob. w tym samym przedmiocie inne dzieła Maritaina: Religion et culture, $72-79 ;$ Du régime temporel et de la liberté, rozdz. III: De la purification des moyens (s. 165-227); Humanisme intégral, Paris 1936, 261-269; L'homme et l'état, $48-68$.

95 Zob. w tekście oryginalnym, s. 70, przyp. 14, o trudnościach, jakie miał Maritain $\mathrm{z}$ przełożeniem ostatniego terminu na język angielski. 
snejaktywności bojowejnad jej cielesnymi środ$\mathrm{kami}$.

Przy tym prawie, mimo częściowo odmiennej terminologii, chodzi o przeciwstawność tych samych zasadniczo środków, o jakich jest mowa w przypadku poprzedniego prawa, mianowicie o przeciwstawność doczesnych środków ubogich i doczesnych środków bogatych, nazwanych tu środkami duchowymi i cielesnymi. Bierze się tylko w stosunku do nich inny cel pod uwagę. Nie jest to już cel duchowy, lecz cel doczesny - ,jakieś dzieło społeczne lub polityczne, które ma, w imię najwyższych dóbr człowieka, sprawiedliwości, wolności, pokoju, przyjaźni braterskiej, przezwyciężyć moc przesądów lub egoizmu, chciwość ambicji lub ucisk władzy".

Według Maritaina działanie omawianego prawa przejawiało sie najczęściej w sposób nadzwyczaj skromny i ukryty w spontanicznej ofierze jednostek wielkodusznych lecz zapomnianych. Sytuacja uległa zmianie dopiero w naszych czasach wraz z wystąpieniem Gandhiego. Jego oryginalność polegała - zdaniem Maritaina - na wyodrębnieniu środków cierpliwości oraz dobrowolnego cierpienia i systematycznego zorganizowania ich w szczególną technikę działania politycznego ${ }^{96}$. Jest to technika, której ideologiczną treść możemy zbliżyć do twierdzenia św. Tomasza $z$ Akwinu ${ }^{97}$, że głównym aktem cnoty męstwa nie jest akt uderzania lecz akt znoszenia, zdobywania się na wytrzymałość lub podejmowania cierpienia w sposób stanowczy ${ }^{98}$. Na podkreślenie zasługuje fakt, że Gandhi zostawił uczniów, którzy podjęli jego metodę Satyagraha. Maritain ma specjalnie na uwadze Winoba Bhave ${ }^{99}$, który osiągnął to, że

96 Zob.: La doctrine du "Satyagraha» exposée par M. K. Gandhi, w książce Maritaina Du régime temporel et de la liberté, 259-270 (tium. tekstu ang., zredagowanego przez Gandhiego jako obszerny przypis do rozdz. IV w Report of the Indian Congress, vol. I, 1920); R. R. Diwakar, Satyagraha: The Power of Truth, Hinsdale III., 1948; Ija Lazari - Pawłowska, Etyka Gandhiego, Warszawa 1965, $23-72,75-93,247-250$.

97 Sum. theol., II-II, qu. CXXIII, zwlaszcza art. 6.

98 Maritain nigdy nie był bezwzględnym wielbicielem wielkiego Hindusa. Zarzucał mu brak zmysłu państwowego oraz podejście nierealne w bezwzględnym wykluczeniu użycia broni. Ale śmiało i z całym naciskiem podnosił, że użycie przez Gandhiego duchowych środków do walki jest wartością pozytywną, która chrześcijanie powinni przejać. Zdaniem Maritaina metoda Gandhiego jest to metoda samego Chrystusa poświęcającego się za ludzi, metoda krzyża, użyta za narzędzie zwycięstwa wielkiej idei. Zob.: Du régime temporel $e^{t}$ de la liberté, 198-202, 209; L'homme et l'état, $62-63$.

Jest widoczne, że Maritain nieco zniekształcił stanowisko Gandhiego przypisując mu bezwzględne wykluczanie użycia broni. Jak pisze Lazari — Pawłowska (dz. cyt., 93), ,zdarzało się jednak, że dla ratowania ludzkiej godności i dla samego zamanifestowania sprzeciwu [Gandhi] wymagał walki zbrojnej". Zob. jeszcze u tej samej autorki 24-25, 34-36, 65, 92-93, 197.

99 Zob. Lanzo del Vasto, Vinôbâ ou le nouveau pèlerinage, Paris 1954; Hallam Tennyson, India's Walking Saint Vinoba Bhave, New York 1955. 
pewni właściciele ziemscy dobrowolnie podzielili i rozdali ziemię wieśniakom żyjącym w nędzy.

Na Zachodzie mamy bardzo mało przejawów aktywności tego rodzaju, jaką podjął Gandhi. Maritain zdołał jedynie wymienić z terenów Europy ruch zainicjowany we Francji przez Ludwika Massignon, a we Włoszech, na Sycylii, przez Danilo Dolci. Szczególne znaczenie przypisuje wielkiemu przykładowi danemu przez Murzynów z Montgomery (stan Alabama) i przez ich przywódcę religijnego — niestety, dziś już nie żyjącego — Marcina Lutra Kinga ${ }^{100}$.

FORMUEY TYPOLOGICZNE ALBO PRAWA WEKTORIALNE.

Formuły te albo prawa odnoszą się - według Maritaina - do et apowości, w jakiej, z pewną koniecznością wewnętrzną, rozwijają się dzieje ludzkie. Charakterystyczne dla nich etapy, stany, odcinki, określone pod względem czasu ich trwania, kierunku i znaczenia, nazywa francuski tomista ,wektorami” historii. Wyodrębnione obecnie przez niego prawa dotyczą poszczególnych ,wektorów" lub relacji zachodzących między nimi. Przy tego rodzaju prawach indukcja ma jeszcze większą rolę do spełnienia niż przy prawach aksjomatycznych 101.

1. Jako pierwsze z praw wektorialnych Maritain wymienia prawo przejścia myśli i kultury ludzkiejod rezimu albo stanu „magicznego" do reżimu albo stanu ,logiczne g o" 102 .

Rozróżnienie đwu reżimów lub stanów, które znalazło uwzględnienie w tym prawie, jest dla Maritaina rozróżnieniem filozoficznym, opartym na filozoficznym poznaniu wyobraźni i umysłu, ich wzajemnych stosunków i ich udziału w postępie wiedzy ludzkiej. U podstaw wskazanego rozróżnienia występują jednak d an e in d ukcy jne dostarczone przez etnologi e, które wskazują na istnienie poważnej różnicy, jaka istnieje między sposobem myślenia człowieka pierwotnego a naszym sposobem myślenia. Te dane indukcyjne znalazły swoistą in te r p r e tac ję w filozoficznym rozróżnieniu przyjętym przez Maritaina, w którym tenże inspirował się w jakiejś mierze teologicznym pojęciem różnych ,stanów”

100 Zob. Maritain, Réflexions sur l'Amérique, tłum. z oryginału ang. [Reflexions on America, New York 1958] Filip Leconte du Noüy, Paris 1958, 51-52.

Por. Lazari - Pawłowska, dz. cyt., 72-74.

101 On the Philosophy of History, 77-78 (Pour une philosophie de l'histoire, $89-90)$.

${ }_{102}$ On the Philosophy of History, 77-104 (Pour une philosophie de l'histoire, $89-114)$. 
natury ludzkiej i różnych ,stanów” rozwoju historycznego ludzkości, jak również uznaną przez siebie za błędną, Heglowską i Comte'owską periodyzacją dziejów.

Do omawianego rozróżnienia francuski tomista doszedł już dawniej, w studium o znaku i symbolu, ogłoszonym w dwu wersjach ${ }^{103}$, z których obszerniejsza weszła do książki Quatre essais sur l'esprit dans sa condition charnelle jako jej roz. II ${ }^{104}$.

W wymienionym studium Maritain wysunął, w łączności z zagadnieniami dotyczącymi znaku praktycznego, rozróżnienie między $\mathrm{z} n$ a kie m logicznym i magicznym ${ }^{105}$. Znakiem logicznym jest dla niego, znak występujący w pewnym stanie funkcjonalnym, w którym - niezależnie od tego, czy ma charakter zmysłowy czy intelektualny — znajduje

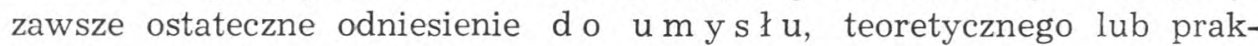
tycznego, stanowiącego dominantę reżimu zaawansowanej kultury $l$ udzkości ${ }^{106}$. Natomiast znak magiczny jest to znak usytuowany w innym stanie funkcjonalnym, bo w stanie, w którym - bez względu na to, czy jest znakiem o naturze zmysłowej czy umysłowej zawsze przemawia ostatecznie do w y obraźni, będącej w ramach tego stanu funkcjonalnego c zyn $\mathrm{nikiem} \mathrm{kierowniczym} \mathrm{calego} \mathrm{in-}$ dywidualnego życia psychicznego i całego życia zaczątkowej kultury ${ }^{107}$. Określenia „logiczny” i „magiczny” wziął francuski tomista $\mathrm{w}$ znaczeniu bardzo szerokim. Przy pierwszym ckreśleniu ma on tylko na uwadze dominację logosu, a nie redukcję wszystkiego do wywodów rozumowych. Przy drugim znów określeniu chodzi mu nie o same działania i wierzenia magiczne, ale o cały reżim psychizmu i cywilizacji pierwotnej, w którym prawem najwyższym jest prawo wyobraźni ${ }^{108}$.

Rozróżnienie między znakiem logicznym i magicznym było dla Maritaina rozróżnieniem próbnym. Opierało się na hipotezie roboczej istnienia dwu wskazanych stanów czy statusów funkcjonalnych umysłu. Jest to hipoteza, po której wprowadzeniu nie musimy interpretować głębokiej różnicy, jaka zachodzi między mentalnością człowieka pierwotnego i kulturalnego, jako różnicę natury, za którą zdawał się opowiadać

103 Sign and Symbol, ,Journal of the Warburg Institute", London, 1 (1937) 1-11; Signe et symbole, "Revue Thomiste”, 44 (1938) 229-330.

104 S. 59-112. Zob. jeszcze dodatek do rozdz. II: Le langage et la théorie du signe (s. 113-124).

105 Swoją ogólną teorię filozoficzną znaku Maritain wyłożył w Quatre essais sur l'esprit dans sa condition charnelle, 60-70. O znaku praktycznym pisze $\mathrm{w}$ tym dziele na s. 70, 72-80.

106 Quatre essais sur l'esprit dans sa condition charnelle, 80-81.

107 Tamże, 81. Por. jeszcze Maritaina Le paysan de la Garonne, Paris 1966, 32, 53-54 (przyp. 2).

108 Quatre essais sur l'esprit dans sa condition charnelle, 82, c. d. przyp. 18. Zob. ponadto s. $83-95,110,119-120$. 
w szeregu dzieł Lucjan Lévy-Bruhl ${ }^{109}$. Możemy założyć, że w obu przypadkach wchodzi w grę ten sam zasadniczo umysł, jak to przyjęli Henryk Bergson ${ }^{110}$ i Olivier Leroy ${ }^{111}$, a tylko stan funkcjonowania umysłu, styl jego działania jest całkowicie inny. To ujęcie uznał za słuszne sam Lévy-Bruhl, gdy zapoznał się z artykułem Maritaina Signe et symbole. Wyrazem ostatecznej precyzacji czy może nawet częściowej zmiany jego stanowiska jest list do Maritaina z 8 V 1938 r. ${ }^{112}$ i Les Carnets ${ }^{113}$. Dodajmy jeszcze, że ujęcie francuskiego tomisty okazuje się także zbieżne z tym, co Bronisław Malinowski pisał w r. 1926 w Magie, Science and Religion o rozumowym ujmowaniu otoczenia przez człowieka pierwotnego ${ }^{114}$.

Eącznie $z$ rozróżnieniem między reżimem albo stanem magicznym i reżimem albo stanem logicznym Maritain przyjął, że droga do tego drugiego etapu prowadzi z konieczności przez pierwszy etap, stanowiący dziecięctwo ludzkości ${ }^{115}$. Na tym etapie znajdowały się najpierw w swej formie zaczątkowej i więcej lub mniej pomieszane z sobą religia, mistyka, poezja, nauka i metafizyka. Nie wystąpiły one po erze magii, a tylko ich stan logiczny nastąpił po stanie magicznym. Nie można na przykład powiedzieć, że magia stanowi przeciwieństwo nauki, lecz

109 Les fonctions mentales dans les sociétés inférieures, Paris 1910; La mentalité primitive, Paris 1922; L'âme primitive, Paris 1927; Le surnaturel et la nature dans la mentalité primitive, Paris 1931; La mythologie primitive, Paris 1935; L'expérience mystique et les symboles chez les primitifs, Paris 1938.

110 Les deux sources de la morale et de la religion, w: Oeuvres, éd. du centenaire, Paris 1959, 1084.

111 La raison primitive, Paris 1927.

112 W tym liście z 8 V 1938, ogłoszonym w numerze kwietniowym ,Revue Thomiste" z wymienionego roku (s. 482-483) i w Quatre essais sur l'esprit dans sa condition charnelle (s. 101, przyp. 3), Lévy - Bruhl pisał m. in.:

„Comme vous le dites très justement, la mentalité «primitive» est un état de la mentalité humaine, et je puis accepter les caractères par où vous la définissez. „Je l'ai étudiée chez les "primitifs» parce qu'elle y paraît plus facile à décrire et à analyser que chez nous, et cette description, cette analyse m'ont fait opposer cette mentalité à la notre. Mais je n'ai jamais dit, ni pensé qu'elle se rencontrât uniquement chez les "primitifs». J'ai même dit le contraire dès les Fonctions mentales. Il faut croire que je m'y suis mal pris, et que j'ai trop insisté sur l'opposition. [...]

„Le «prélogisme» [...], je n'en ai pas eu l'idée. Je pense seulement que cet état, décrit et analysé sous le nom de «mentalité primitive» a ses caractères propres, sans por cela supposer que ces esprits sont bâtis autrement que les nôtres".

113 Paris 1949, Carnet VI, 135. - „J'ai été amené, trop vite - pisał $m$. in. w cyt. miejscu Lévy - Bruhl - à conclure de cette observation des faits, à un caractère "prélogique» de la mentalité primitive. Je les comprends mieux aujourd" hui, et j'ai reconnu, [...] que la mentalité primitive est, en réalité, un aspect, un état (Maritain) de la mentalité humaine en général [...]".

Obok wpływu Maritaina zaznaczył się jeszcze u Lévy - Bruhla w Les Carnets wpływ etnologa holenderskiego G. Van der Leeuwa, na który zwrócił uwagę Armand Cuvillier (Alfred Weber i Denis Huisman oraz inni, Tableau de la philosophie contemporaine, Paris 1957, 617).

114 W nowszym wyd. „Anchor Books” 33-34 (w tlum. polskim T. Swięcickiej:

Bronisław Malinowski, Szkice z teorii kultury, Warszawa 1958, 407-408).

115 Quatre essais sur l'esprit dans sa condition charnelle, 83. 
tylko, że stan magiczny nauki przeciwstawia się jej stanowi logicznemu ${ }^{116}$.

Z tymi spostrzeżeniami dość wcześnie, bo już w artykule Signe et symbole, francuski myśliciel wyodrębnił prawo dziejów ludzkich, które w On the Philosophy of History potraktuje jako jedno $\mathrm{z}$ praw wektorialnych.

2. Z kolei omawia Maritain prawo postępu świ adomości moralnej, które uważa za jedno z najważniejszych praw, jakie zna filozofia historii" ${ }^{117}$.

Według niego ,,istota, a nawet wartość postępowania moralnego, prawość i czystość świadomości moralnej są niezależne od wyraźnego poznania wszystkich szczegółowych praw moralnych". Stanowi to moment szczególnie pozytywny, gdyż - jak sądzi Maritain - nasze spontaniczne i naukowe poznanie praw moralnych, będąc powolną refleksją krytyczną nad historycznym, niejednokrotnie uwarunkowanym przez określone struktury społeczne doświadczeniem moralnym ludzkości ${ }^{118}$, posiada ze swej natury charakter progresywny, tak że wyraźna świadomość szczegółowych norm prawa naturalnego wzrasta wraz z czasem, a nawet niektóre $z$ nich, jak na przykład prawo monogamii, zostały poznane przez ludzkość stosunkowo późno, o ile o tym wiemy na podstawie badań naukowych. Chodzi tu o postęp w poznaniu szczegółowych praw moralnych, który nie musi łączyć się z postępem w życiu moralnym takich czy innych społeczności.

Maritain wymienia kilka przykładów postępu świadomości moralnej.

Obecnie zdajemy sobie sprawę $z$ tego, że niewolnictwo jest przeciwne godności osoby ludzkiej. Posiadamy także inne niż w przeszłości poglądy na traktowanie więźniów wojennych. „Podczas całych wieków, a nawet w wiekach chrześcijańskich, uważano za rzecz całkowicie normalną zabijanie więźniów wojennych. Nie czyniono różnicy między nieprzyjacielskim żołnierzem walczącym a żołnierzem nieprzyjacielskim, który został więźniem. Jeżeli więźniowi wojennemu darowano życie, było to uważane za łaskę, za którą płaciło się popadnięciem w stan niewolniczy, uważany wówczas za coś uprawnionego. Dziś mamy poglądy zupełnie inne w przedmiocie naszych zobowiązań dotyczących więźniów wojennych".

Inny przykład postępu świadomości moralnej znajdujemy w ustosunkowaniu się do pracy dzieci. „Na początku epoki przemysłowej uważano

116 Tamże, 96-106. - O losach myśli magicznej i znaku magicznym w stanie logicznym zaawansowanej kultury Maritain pisze na s. 106-112.

117 On the Philosophy of History, 104-111 (Pour une philosophie de l'histoire, 114-121). Por. jeszcze Maritaina Religion et culture, 30.

118 Przy tym doświadczeniu Maritain ma na uwadze dążności i skłonności istotne dla natury ludzkiej, lub inaczej się wyrażając - nasze skłonności podstawowe (the basic inclinations). 
prace dzieci za coś całkowicie uprawnionego. Obecnie mamy inne zdanie w tej sprawie i ono jest na pewno bardziej zgodne z prawem naturalnym".

W naszych czasach zmieniły się także poglądy na warunki pracy ludzkiej. „Idea, że praca mas jest niemożliwa bez bicza nędzy — idea szeroko rozpowszechniona w XIX wieku - zdawała się wówczas być w zgodzie $\mathrm{z}$ prawem naturalnym. Nawet religia i błędny oraz tendencyjny sposób rozumienia kary Adama, przedstawionej w Księdze Rodza$j u$, były eksploatowane $\mathrm{w}$ tym sensie. Ale teraz rozumiemy, na czym polega wielki błąd tej koncepcji".

Jeszcze jeden przykład: „Idea, że sprawowanie autorytetu jest niemożliwe bez znacznego udział̉u arogancji i brutalności, idea odrzucająca w cień wszelkie poczucie braterstwa ludzkiego między tym, który rozkazuje, a"tym, który słucha, jest innym pojęciem, jakie długo zdawało się być czymś oczywistym. Obecnie jest ono uważane za wyraz błędu, gdyż dokonał się postęp w naszym poznaniu tego, czego natura ludzka domaga się ze swej głębi w naszych wzajemnych relacjach i w atmosferze moralnej naszego życia wspólnego".

3. Na jedno $z$ praw wektorialnych historii składa się u Maritaina prawo przejścia od cywilizacji, ,sakralnych" do cywilizacji, świeckich" albo, "laickich" 119. Prawo to, przy którym wyraz „cywilizacja” został wzięty w znaczeniu kultury społecznej120, francuski filozof rozpatruje głównie w zastosowaniu do dziejów Europy od średniowiecza do naszych czasów.

Według niego średniowiecze zrealizowało sakralną cywilizację chrześcijańską. Charakteryzowało ją najpierw to, że jedność wiary była wymagana do jedności politycznej, tak że, w następstwie tego, powstał organizm społeczny natury polityczno-religijnej, jakim była respublica christiana. A dalej, dominującą

119 On the Philosophy of History, 111-115 (Pour une philosophie de l'histoire, 121-125).

Por. jeszcze: wersja ang. wymienionego dzieła, 69, tłum. franc., 82; Religion et culture, 27-37; Du régime temporel et de la liberté, 46-50, 124-130; L'idéal historique d'une nouvelle chrétienté, w: Magister Thomas - Doctor communis, 85-86, 90-91, 98-99; Humanisme intégral, 156-221; L'homme et l'état, 146-150.

Jedna z cytowanych pozycji, mianowicie L'idéal historique..., jest to prelekcja wygłoszona w Poznaniu 29 VIII 1934 r. na drugim zebraniu plenarnym międzynarodowego kongresu filozofii tomistycznej, powtórzona później na uniwersytecie w Ottawie. Tekst prelekcji poznańskiej ukazal się najpierw z pewnymi dodatkami W „La Vie Intellectuelle”, 33 (1935) 181-232. Dla większej przejrzystości autor wprowadził do artykułu podziały i podpodziały. Prelekcja w tej formie, w jakiej została wygłoszona, znajduje się w Księdze pamiątkowej wymienionego kongresu międzynarodowego. Stanowi ona rozwinięcie sześciu wykładów pt. Problèmes spirituels et temporels d'une nouvelle chrétienté, wygłoszonych przez Maritaina w sierpniu 1934 r. W Santander.

${ }_{120}$ To znaczenie przyjmuje $w$ polskiej literaturze naukowej Bogdan Nawroczyński (Życie duchowe - Zarys filozofii kultury, Kraków - Warszawa 1947, $240-244)$. 
ideą dynamiczną była w średniowiecznej sakralnej cywilizacji chrześcijańskiej idea siły w służbie sprawiedliwości.

Czasy nowożytne są znów - zdaniem Maritaina - wiekami ś w i e ckimi pod względem swych form cywilizacyjnych. Porządek społeczności doczesnej zdobył w tych czasach swe całkowite wyodrębnienie i swą pełną a utonomię we własnej sferze. Były to zmiany $\mathrm{w}$ sobie normalne i odpowiadające ewangelicznemu rozróżnieniu między dziedziną Boga i dziedziną „Cezara”. To, co z religijnego punktu widzenia nazwie się wypaczeniem tego procesu prawidłowego, była to dężność do odizolowania sfery życia społecznego i politycznego od Boga i Ewangelii, a ostatecznie do odrzucenia wszelkiej transcendencji.

W następstwie zróżnicowania, o którym dopiero co była mowa, dominującą ideą dynamiczną cywilizacji nowożytnej stała się nie•idea siły w służbie sprawiedliwości, ale raczej idea zdobycia wolności i warunków społecznych odpowiadajacych godnośc i l u d zki e j. Zdrowa współpraca między Kościołem i państwem nie wyraża się już jednością organizmu społecznego o charakterze polityczno-religijnym, lecz koncentruje się na osobie ludzkiej, która jest równocześnie członkiem państwa i Kościoła. J edność religi i nie jest obecnie wymagana do jedności politycznej. Wszyscy, niezależnie od swego stosunku do religii, uczestniczą $\mathrm{w}$ tym samym wspólnym dobru swej społeczności politycznej i pracują na jego rzecz.

Maritain sądzi, że liczenie się z rozwojem Europy od cywilizacji sakralnej do cywilizacji świeckiej pozwala na poprawne ujęcie stosunków między Kościołem i państwem w naszej epoce, a także na sformułowanie takiego konkretnego ideału historycznego, który byłby dostosowany do tworzącejsię obecniecywilizacji (świecka koncepcja cywilizacji chrześcijańskiej). Tymi zagadnieniami francuski tomista zajął się bliżej w pracach: Du régime temporel et de la liberté ${ }^{121}$; L'idéal historique d'une nouvelle chretienté ${ }^{122}$; Humanisme intégral ${ }^{123}$; Man and the State. ${ }^{124}$.

Zdaniem Maritaina rozróżnienie między cywilizacją sakralną i cywilizacją świecką, wprowadzone do interpretacji rozwoju, jaki dokonał się w świecie chrześcijańskim, to rozróżnienie, które ze strony tomistycznej podjął również ks. Journet ${ }^{125}$, może także stanowić $\mathrm{kl} \mathrm{u} \mathrm{c} \mathrm{z} \mathrm{do} \mathrm{spre-}$ cyzowania natury innych form cywilizacji. Chodzi tu

121 S. 123-131 (La notion d'idéal historique concret).

122 Jak wyż., 91-114

123 S. 175-310. - Wysuwany $\mathrm{w}$ tym dziele $\mathrm{i}$ w dwu poprzednio cytowanych pracach konkretny ideał historyczny analizowalem w art. Nowy typ cywilizacji chrześcijańskiej w ujęciu J. Maritaina, „Przegląd Powszechny”, 226 (1948) 213-222.

124 W cyt. wyż. tłum. franc., 137-175 (rozdz. VI: L'Église et l'État).

${ }^{125}$ L'Église du Verbe incarné, Paris $1949^{1}, 1955^{2}, 269-425$. 
o rozpatrzenie $\mathrm{m}$. in., w jakim znaczeniu cywilizacja Indii jest cywilizacją sakralną; czy cywilizacja sakralna tego typu co cywilizacja Islamu mogłaby z czasem przybrać charakter świecki?

Rozróżnienie między cywilizacją sakralną i świecką pozwala również — według Maritaina - na ustalenie typu cywilizacji g reckiej. I tak - jego zdaniem - nie była ona cywilizacją świecką, gdyż Grecy nie rozróżniali między czynnikiem politycznym i religijnym. Ale cywilizacja grecka nie była także cywilizacją sakralną w sensie ścisłym, w jakim pojawiła się w chrześcijaństwie i w Islamie. Można by ją nazwać cywilizacją hi eropolityczną, gdyż w jej ramach organizm polityczny posiadał najwyższą godność w przyjmowanej. wówczas skali wartości i był obarczony funkcjami religijnymi ${ }^{126}$. Ta cywilizacja hieropolityczna nie znała emergencji pierwiastka wiecznego w człowieku ponad społeczność doczesną.

4. Ostatnim prawem wektorialnym, jakie Maritain uwzględnia, jest prawo politycznego i społecznego dojścia ludu do pełnoletności ${ }^{127}$. Prawu temu poświęca zaledwie parę uwag.

Proces, o jaki mu chodzi, jest to stopni owe przejście ludu w czasach nowożytnych ze stanu poddaństwa do stanu samorządu (self-government) w materii politycznej i społecznej. Reżim cywilizacyjny, który stanowi kres omawianego procesu, charakteryzuje się postawą demokratyczną, znajdującą uzasadnienie w odpowiedniej filozofii. Nowa orientacja zaznaczyła się najpierw w życiu politycznym, a dopiero później zaczęła się stopniowo przejawiać w płaszczyźnie życia społecznego. Zdaniem Maritaina wskazany proces znajduje się dopiero w swych pierwszych fazach, które przedstawiają się bardzo niejednolicie u różnych narodów współczesnych.

Prawo politycznego i spolecznego dojścia ludu do pełnoletrości znajduje zakotwiczenie $\mathrm{w}$ podstawowych aspiracjach i skłonnościach natury ludzkiej. Niemniej jednak jego działanie uwidoczniło się - zdaniem Maritaina - dopiero wtedy, gdy zaczyn ewangeliczny zaczął inspirować świadomość spoleczeństwa świeckiego (secular consciousness) W przedmiocie życia politycznego i społecznego ${ }^{128}$. Stąd też - jak twierdzi francuski filozof - nurt demokratyczny pojawił się najpierw „w tym obszarze cywilizacji, który jest dziedzictwem historycznym średniowiecznego chrześcijaństwa zachodniego".

126 Określenie koncepcji greckiego miasta - państwa jako koncepcji totalitarnej, które znajdujemy m. in. u Marrou (Histoire de l'éducation dans l'antiquité, Paris 1948, w szczególności cz. I i II), Maritain uważa za blędne.

${ }^{127}$ On the Philosophy of History, 115-117 (Pour une philosophie de l'histoire, $125-127)$.

128 Zagadnieniem tym Maritain zajął się w książce tłumaczonej na szereg języków Christianisme et démocratie, New York, éd. de la Maison française, 1943. 
Spróbuję teraz omówić krytycznie niektóre zagadnienia, głównie epistemologiczne i metodologiczne, jakie narzucają się $\mathrm{w}$ przedmiocie wykładu Maritaina o prawach dziejów ludzkich, rozumianych jako prawidłowości tych dziejów. Przeanalizuję najpierw ich stosunek do c złowieka oraz zróżnicowanie ich formuł pod względem metodologicznym. Następnie poruszę bardziej szczegółowe problemy metodologiczne i merytoryczne, odnoszące się do wyodrębnionych przez Maritaina praw funkcjonalnych i wektorialnych.

1. Biorąc pod uwagę najogólniejsze wypowiedzi Maritaina o prawach historii oraz treść, jaką on nadał poszczególnym ich formułom, musimy zauważyć, że te prawa nie stanowią dla niego jakiegoś transcendentnego czynnika pozaosobowego, lecz są rzutowaniem w tok dziejów natury ludzkiej, funkcją tej natury wziętej z całym jej duchowym wyposażeniem, a więc z życiem intelektualnym i wolitywnym - natury zasadniczo niezmiennej, ale rozwijającej się progresywnie w sensie przypadłościowym pod względem refleksyjności, w zakresie świadomości moralnej, a także w trakcie równoczesnej, krzyżującej się ze sobą realizacji dobra i zła, w zadzierzganiu się witalnej jedności pewnych narodów, w politycznym i społecznym dochodzeniu ludu do pełnoletności oraz - w przypadku akceptacji czy brania pod uwagę stanowiska religijnego - w dążeniu do uzyskania autonomii dla porządku doczesnego w jego własnej sferze. W tym ujęciu zmierzającym do uwypuklenia cech charakterystycznych praw historii, nigdzie formalnie nie wyrażonym przez Maritaina, chociaż obiektywnie implikowanym przez jego wypowiedzi, zasadnicza niezmienność natury ludzkiej, wziętej nie tylko w aspekcie statycznym, lecz również dynamicznym, warunkuje niewątpliwie tę dozę konieczności i bardzo ramowego determinizmu, jaka występuje w wymienionych prawach, gdy w ich formulach dochodzą do głosu pewne ogólne rysy dziejów ludzkich i zaznaczają się w nich podstawowe struktury. Ok reślenie szczegółowych orientacji dziejów ludzkich należy znów w analizowanym ujęciu do Boga, o ile dzieje ludzkie zależą od Jego planów, i do wolnej woli lu d zki ej. Maritain dochodzi więc do odrzucenia powszechnego determinizmu w historii na drodze dedukcyjnej, wni oskowania, biorąc za punkt wyjśsia tezę o wolnejwoli człowieka i tezęo działaniu Opatrzności. W ten sposób unika trudności, z jakimi boryka się Nagel, który nie uwzględnia $\mathrm{w}$ gruncie rzeczy tych przesłanek, i - w następstwie tego - jest zmuszony przyznać, że powszechny determinizm w hi- 
storii ani nie został definitywnie udowodniony, ani też nie daje się definitywnie obalić ${ }^{129}$.

Rozróżnienie między funkcjonalnymi i wektorialnymi prawami historii nie jest czymś specjalnie charakterystycznym dla Maritaina. Wyodrębnia je również $\mathrm{m}$. in. Jerzy Topolski ${ }^{130}$, który nazywa jeszcze pierwsze $z$ nich prawami synchronicznymi, strukturalnymi ${ }^{131}$, a drugie - diachronicznymi, przyczynowymi ${ }^{132}$. Przeprowadził on nawet metodologiczną analizę obu rodzajów praw głębiej niż Maritain wskazując, że prawa funkcjonalne dotyczą wzajemnych uzależnień równoczesnych, czyli sprzeżeń równoległych między faktami historycznymi, a prawa kierunkowe „dadzą się ująć w formie sprzężeń szeregowych, zakładających upływ czasu między wyjściem elementu, stanowiącego przyczynę, a wejściem elementu, będącego skutkiem" ${ }^{133}$. Topolski poruszył ponadto nie podjęte przez Maritaina zagadnienie sprowadzalności praw funkcjonalnych do kierunkowych ${ }^{134}$.

W stosunku do polskiego metodologa historii Maritain okazuje się mniej konsekwentny $\mathrm{w}$ zaliczaniu poszczególnych praw do wskazanych ich dwu rodzajów. Prawo progresywnego wzrostu świadomości i prawa dotyczące hierarchii środków do celów duchowych oraz doczesnych (społecznych lub politycznych) nie są czystymi prawami funkcjonalnymi, jak chce Maritain, gdyż nie jest dla nich obojętny upływ czasu między elementem dziejów składającym się na przyczynę a ich elementem stanowiącym skutek. Posługując się terminologią Topolskiego ${ }^{135}$ powiemy, że są to prawa synchroniczno-diachroniczne, prawa strukturalno-ki erunkowe, prawa rozwoju historycznego dotyczące sprzężeń zwrotnych, ujemnych i dodatnich. Dla przyjętej dla nas interpretacji nie stanowią trudności prawa odnoszące się do hierarchii środków, jeżeli zgodzimy się, że do ich uświadomienia dochodzi na pewnym dość późnym etapie rozwoju refleksyjności i wysubtelnienia świadomości moralnej.

Prawa znów określone przez Maritaina jako prawa wektorialne, kierukowe, nie są takimi prawami w czystej po-

129 Dz. cyt., 507-518. - Zagadnieniem definicji determinizmu dziejowego Nagel zajął się na s. 508-509.

130 Dz. cyt., 188-199.

131 Nazwa ta pochodzi niewątpliwie stąd, że zdarzenia stale występujące razem, których dotyczą prawa synchroniczne, prawa współistnienia, „tworzą pewną prawidłową strukturę zdarzeń", jak się wyraża Oskar Lange (Ekonomia polityczna, t. I, Warszawa 1959,50$)$.

132 Jak się zdaje, Topolski przejął rozróżnienie między prawami synchronicznymi (funkcjonalnymi) i diachronicznymi (kierunkowymi) od Maurycego Mandelbauma. Zob. Topolskiego dz. cyt., 189, przyp. 1.

133 Tamże, 189.

134 Tamże, 1. c. i $166-167$.

135 Dz. cyt., 189, 199. 
s ta ci, gdyż nie dają się pomyśleć bez wejścia w grę sprzężeń równoległych. Na przykład, gdy idzie o prawo postępu świadomości moralnej, to wyrażony w nim postęp w zakresie wyraźnego poznania szczegółowych norm prawa naturalnego jest funkcją refleksji krytycznej nie tylko dawniejszych pokoleń nad doświadczeniem moralnym ludzkości, ale również jednostek współcześnie żyjących. Prawa, potraktowane przez Maritaina jako wektorialne, są, podobnie jak dwa ostatnio wymienione przez niego prawa funkcjonalne, prawami synchroniczno-diachronicznymi, jak wyrazilibyśmy się w terminologii Topolskiego. Możemy w tym tylko przyznać słuszność Maritainowi, że w nich moment wektorowy, moment kierunkowości, odgrywa wyróżniającą się rolę.

Narzuca się jeszcze kilka spostrzeżeń natury ogólnej. Jedno z nich dotyczy typu epistemologicznego formul wyodrębnionych przez Maritaina praw historii. Okazuje się, że nie we wszystkich spośród nich charakter opisowy góruje nad aspektem uwzględnionych w nich wartości, jak należałoby się spodziewać. W prawie ambiwalencji historii i prawach hierarchii środków aspektaksjologiczny przeważa niewątpliwie nad ich stronąopisow ą. W związku z tym nasuwa się uwaga natury metodologicznej, że przynajmniej prawo hierarchii środków zostało ustalone ni e z po m o c ą in d u k c ji (enumeracyjnej niezupełnej), stanowiącej dla Maritaina podstawową metodę filozofii historii, lecz na drodze apriorycznej, w oparciu o aksjomat proporcjonalności porządku środków do porządku celów. Gdy znów idzie o prawa, które zostały w sposób widoczny wprowadzone na bazie wskazanej indukcji, to tego rodzaju ich geneza nie została przez Maritaina dostatecznie opracowana. Jedynie przy prawie przejścia myśli i kultury ludzkiej od reżimu albo stanu „magicznego" do reżimu albo stanu ,logicznego" wyzyskał nieco więcej dane etnologii.

2. Szczegółowe uwagi dotyczące praw historii, które zostały nazwane przez Maritaina prawami funkcjonalnymi, ograniczę do prawa podwójnego postępu antagonistycznego i praw hierarchii środków, gdyż pozostałe prawa nie nasuwają specjalnych problemów.

W przedmiocie pierwszego prawa nie ulega wątpliwości, że rzeczywistość w jego formule zakładana jest bardziej zgodna ze stanem faktycznym niż to, co ks. Michalski przyjmował w perfekcjorystycznej koncepcji dziejów, mianowicie ciągłą ewolucję życia kulturalno-społecznego ludzkości od form mniej doskonałych ku formom bardziej doskonałym. Na gruncie polskim krytycznej konfrontacji stanowiska Maritaina ze stanowiskiem zajętym przez ks. Michalskiego dokonał już Swieżaw- 
ski ${ }^{136}$. Wskazał on na nieadekwatność idei perfekcjoryzmu historycznego wobec rzeczywistości dziejowej, a ponadto zauważył, że gdy ks. Michalski doszukiwał się tej idei u Akwinaty, to, ,jak się wydaje, z tekstu Tomaszowego wyciągnął zbyt daleko sięgające wnioski" ${ }^{137}$. Do tych uwag, z którymi Swieżawski stanął po stronie ujęcia Maritaina z On the Philosophy of History, trzeba wszakże dodać, że w późniejszym dziele, w Le paysan de la Garonne ${ }^{138}$ francuski myśliciel podjął coś z optymizmu właściwego dla perfekcjoryzmu historycznego, gdy napisał, że choć w dziejach dobro i zło wzrastają równocześnie, to jednak dobro wzrasta w większym stopniu ${ }^{139}$.

Maritain nie dał $\mathrm{z}$ historii ścisłego uzasadnienia indukcyjnego dla prawa podwójnego postępu antagonistycznego. Nie dał również uzasadnienia z podzielanej przez siebie filozoficznej koncepcji człowieka, która mogła mu się narzucać bardziej bezpośrednio jako podstawa wymienionego prawa. Mam tu na uwadze fakt występowania w każdym człowieku przeciwstawnych sobie dążności do dobra i zła, których rezonans w dziejach ludzkości trudno sobie przedstawić inaczej jak pod postacią prawa podwójnego postępu antagonistycznego. Uzasadnienie, jakie dla niego przedstawił Maritain, ma postać argumentacji teologicznej, w której inspiruje się on ewangeliczną przypowieścią o kąkolu (Mt 13, 24-30, 36-43) ${ }^{140}$ względnie innymi jeszcze tekstami Nowego Testamentu ${ }^{141}$. Daremnie jednak szukalibyśmy u Maritaina tego rodzaju uzasadnienia dla jego twierdzenia, że wzrost dobra przeważa w dziejach nad wzrostem zła. Za tym twierdzeniem nie podał on również żadnego uzasadnienia indukcyjnego.

Z praw ,funkcjonalnych" Maritaina szczególne zainteresowanie budzą prawa dotyczące hierarchii środków do celów duchowych i doczesnych (społecznych lub politycz$\mathrm{nych}$ ), gdyż formuły tych praw nie tylko głoszą w swej treści o charakterze prakseologicznym wyższość doczesnych środków ubogich, ducho-

136 Dz. cyt., 525, 532-535.

137 Swieżawski wprowadził jednakże do swej niewątpliwie słusznej krytyki pewien akcent zbyt ostry, gdy w jej kontekście napisał o ,zasadniczo naiwnej koncepcji perfekcjonizmu historycznego" (s. 533). Nie można zapominać o tym, że ks. Michalski zdawał sobie sprawę z trudności podzielanej przez siebie idei, a nie rezygnował z niej dlatego tylko, że sądził, iż wystarcza w przypadku napotkanych trudności uciec się do wiary w Opatrzność, , która z irracjonalnych dia nas powikłań dziejowych potrafi wyprowadzić jednostki i państwa na szerokie gościńce rozwoju". (Tomizm wobec wspólczesnej filozofii dziejów, w: Magister Thomas Doctor communis, 27). Gdyby ks. Michalski przemyślał był dokładniej trudności perfekcjoryzmu historyzmu, zająłby może stanowisko bliskie tego, jakie wyraża Maritainowe prawo podwójnego postępu antagonistycznego.

138 S. 64.

139 Maritain wyraził się ogólnikowo, w sposób obiektywnie niejednoznaczny: le bien cependant y grandit davantage.

${ }_{140}$ On the Philosophy of History, 44 (Pour une philosophie de l'histoire, 57-58).

141 Le paysan de la Garonne, 49-62. 
wych, nad doczesnymi środkami bogatymi, cielesnymi, lecz ukazują jeszcze pośrednio perspektywy dalszego uduchowienia działań ludzkich nawet w sferze aktywności czysto doczesnej. W przedmiocie tych praw poruszę sprawę ich uzasadnienia.

Jak już zaznaczyłem, Maritain uzasadnia je nie $z$ pomocą indukcji (enumeracyjnej niezupełnej), a więc nie aposteriorycznie, lecz apriorycznie odwołując się do aksjomatu głoszącego konieczność dostosowania środków do podjętych celów. Tego rodzaju uzasadnienie wystarcza bez żadnych wątpliwości w odniesieniu do prawa wyższości doczesnych środków ubogich nad doczesnymi środkami bogatymi przy dążeniu do celów duchowych. Ale odwołanie się do wskazanego aksjomatu nie może wystarczyć przy argumentacji za prawem wyższości duchowych środków doczesnej aktywności bojowej nad jej cielesnymi środkami. W przypadku tego prawa trzeba jeszcze uwzględnić jakieś dodatkowe przesłanki. Maritain tej sprawy metodologicznej bliżej nie opracował, niemniej jednak wprowadził do swych wywodów dodatkowe przesłanki, gdy napisał, że celem korelatywnym do środków duchowych działalności doczesnej jest ,jakieś dzieło społeczne lub polityczne, które ma, w i mi ę najwyższych dóbr człowieka, sprawiedliwości, wolności, pokoju, przyjaźni braterskiej j142, przezwyciężyć moc przesądów lub egoizmu, chciwość ambicji lub ucisk władzy". Jest to argumentacja, którą można by dalej rozwijać. Jeżeli Maritain poprzestał na jej bardzo szkicowym ujęciu, tłumaczy się to tym, że — jak się zdaje - do praw hierarchii środków doszedł na drodze myślenia nie tyle filozoficznego co teologicznego. Wskazywałyby na to wypowiedzi Maritaina, że do środków doczesnych ubogich należy podjęcie krzyża (la Croix est en eux), że metoda Satyagraha była to u Gandhiego metoda samego Chrystusa poświęcającego się za ludzi, metoda krzyża użyta za narzędzie zwycięstwa wielkiej idei.

3. Z praw historii, potraktowanych przez Maritaina jako prawa w e ktorialne, zwracają uwagę trafnością swego ujęcia prawo przejścia myśli i kultury ludzkiejod réimu albo stanu „magi czneg c" do reżimu albo stanu „logicznego" i prawo przejścia od cywilizacji ,sakralnych" do cywilizacji, ,świeckich" a lbo "laickich".

Rozróżnienie dwu reżimów lub stanów, które znalazło wyraz w pierwszym z tych praw, umożliwia: a. pozytywne ustosunkowanie się do danych etnologii wskazujących na poważną różnicę, jaka zachodzi między sposobem myślenia człowieka pierwotnego i naszym, oraz b. podtrzymywanie tezy, że w przypadku obu reżimów czy stanów dochodzi do głosu

142 Podkreślenie moje. 
ten sam zasadniczo umysł. Maritainowi udało się zharmonizować to, z czym przeź długi czas nie mógł zadowalająco uporać się Lévy-Bruhl, chociaż i on, mimo przejaskrawień w przedmiocie mentalności ,prymitywnej", był zawsze przekonany - jak można sądzić na podstawie jego wyznań - że umysły pierwotne nie są inaczej , zbudowane" niż nasze ${ }^{143}$. O tym, jak powszechne zastosowanie posiada wprowadzone przez Maritaina rozróżnienie, świadczy może najlepiej to, że można się nim posłużyć w przypadku religii bez zniekształcenia jej genezy.

Pozytywną ocenę prawa przejścia od cywilizacji, ,s akralnych" do cywilizacji, św i eckich" a lbo ,l a i ckich" może utrudniać brak dostatecznie adekwatnego odczytania jego sensu, które - jak się zdaje - wystąpiło m. in. u Tadeusza Mrówczyńskiego. Autor ten utrzymuje: ,Pojęcie cywilizacji chrześcijańskiej czy społeczności chrześcijańskiej jest dość mgliste i nieokreślone. Nie wiadomo dokładnie, czym ma się różnić taka cywilizacja czy społeczność od cywilizacji czy społeczności niechrześcijańskiej. Znamię chrześcijańskiej koncepcji życia, o którym pisze Maritain, jest kryterium równie elastycznym i pozastawiającym szeroki margines dla różnorodnych interpretacji i ocen" ${ }^{144}$. Tę swoją krytykę Mrówczyński łagodzi tylko, ale nie usuwa uwagą, że ,podane przez Maritaina określenie cywilizacji chrześcijańskiej służy nie tyle do odróżnienia cywilizacji, które noszą na sobie znamię chrześcijańskiej koncepcji życia, od wszelkich innych cywilizacji, co uzasadnieniu tezy o wielości możliwych wcieleń doczesnych chrystianizmu" 145. Ale zastrzeżenia wysunięte przez Mrówczyńskiego nie zdają się być uzasadnione, gdyż Maritainowi, mimo pewnych niekonsekwencji, chodzi najwyraźniej o taką koncepcję cywilizacji, która - przy gatunkowo (istotnie) odmiennych od średniowiecznych i nieodwracalnych warunkach realizacji - byłaby do przyjęcia zarówno przez chrześcijan, jak i przez niechrześcijan czy w ogóle niewierzących. Maritainowi można by tylko zarzucić nie dość precyzyjną terminologię, gdyż powinien był pisać nie o chrześcijańskiej cywilizacji świeckiej, ale o cywilizacji świeckiej, w której mogliby również uczestniczyć czynnie chrześcijanie, inspirując się swoimi wierzeniami religijnymi. Jeżeli Maritainowi chodzi o cywilizację możliwą do przyjęcia niezależnie od ustosunkowania się jednostki do religii, odpada także dalszy zarzut Mrówczyńskiego ${ }^{146}$ powtórzony za Janem Lacroix ${ }^{147}$, że w nowej cywilizacji chrześcijańskiej ugrupowania niechrześcijańskie byłyby tylko tolerowane. Przy przyjętym

143 Zob. wypowiedzi Lévy - Bruhla zamieszczone w przypiskach 112 i 113.

144 Personalizm Maritaina i wspótczesna myśl katolicka, Warszawa 1964, 176.

145 Tamże, 1. c.

146 Dz. cyt., 192-193.

147 Sens dialogu (Wybór pism), tłum, Wanda Tazbirówna, Mieczysław Tazbir i Jacek Woźniakowski, Warszawa 1957, 28. 
przez nas rozumieniu Maritainowej koncepcji „chrześcijańskiej” cywilizacji świeckiej prawo przejścia od cywilizacji ,,sakralnych” do cywilizacji ,,świeckich" albo ,laickich" będzie się narzucało jako konieczność dziejowa, uwarunkowana zaistnieniem w czasach nowożytnych spoleczeństwa pluralistycznego pod względem światopoglądowym.

§. 3. PROPONOWANE PRZEZ MARITAINA UJĘCIE STOSUNKÓW MIĘDZY WOLNOŚCIĄ BOŻĄ A WOLNOŚCIĄ LUDZKĄ W KSZTAETOWANIU HISTORII.

1. Według Maritaina problemem najbardziej fundamentalnym filozofii historii jest problem stosunków zachodzących między wolnością Bożą a wolności ą ludzką w kształtowani u h is to rii. Analizując dość szczegółowo to zagadnienie w Saint Thomas and the Problem of Evil 148, a zwłaszcza w Court traité de l'existence et de l'existant (Paris 1947), roz. IV: L'existant libre et les libres desseins éternels ${ }^{149}$, Maritain ograniczył się w On the Philosophy of History do streszczenia swych poglądów ${ }^{150}$. Streszczenie to jest jednak tak lakoniczne, że do tego, by stało się w. pełni zrozumiałe, musimy uwzględnić pełniejsze wypcwiedzi francuskiego filozofa, sięgając nawet do jego późniejszej pracy Dieu et la permission du mal (Paris 1963) ${ }^{151}$, w której on podejmuje polemikę ze swym krytykiem, o. Janem Hervé Nicolas OP, autorem obszerniejszego artykułu La permission du péché ${ }^{152}$. Za syntetycznym uwzględnieniem wszystkich dopiero co wskazanych tekstów przemawia również to, że są wyrazem jednego stanowiska, które z upływem czasu znalazło coraz większe pogłębienie.

2. Wywody w przedmiocie zagadnienia czy - ściślej się wyrażając — w przedmiocie tajemnicy zła Maritain zaczyna od twierdzenia, że Bóg nie jest w żadnej mierze, nawet pośrednio, przyczyną zła moralnego jako takiego. To zło ma swe bliższe źródło w człowieku, w jego w oln y m nie zwracaniu uwagi na regułę moralną ${ }^{153}$, jak to sze-

148 The Aquinas Lectures, 1942. Przekład G. Andison, Milwaukee 1942, SS. V + 46. W wersji franc.: Saint Thomas d'Aquin et le problème du mal jako roz. VII książki De Bergson à Thomas d'Aquin - Essais de Métaphysique et de Morale, Paris 1947, 269-272, 282-301.

149 S. $141-195$.

150 S. 119-120 (Pour une philosophie de l'histoire, 129-133).

151 Zob. w szczególności s. $27-31,37-59$.

152 „Revue Thomiste”, 60 (1960) 5-37, 185-206, 509-546.

153 Jak pisze Maritain w Dieu et la permission du mal (s. 39), ,la non-considération de la règle [...] n'est pas [..] un acte de non considération, mais un non-acte de considération".

Już w eseju Saint Thomas d'Aquin et le problème du mal (De Bergson à Thomas d'Aquin..., 290) Maritain utrzymywał: „A un premier temps [du mouvement de la volonté dans l'acte de choix mauvais] il y a absence de la considération de 
rzej przedstawił św. Tomasz z Akwinu w quaestio disputata De malo, qu. I, a. $3^{154}$. Stąd też - zdaniem Maritaina - trzeba powiedzieć, że w rzeczywistości egzystencjalnej świata człowiek jest pierwszą przyczyną zła moralnego. Ma tu chodzić o przyczynowość w sensie negatywn y m, w linii niebytu.

$\mathrm{Na}$ uwagę zasługuje interpretacja, jaką francuski tomista przyjął dla nie myślenia aktualnego o regule moralnej. Jest to interpretacja, która zaważyła na całej jego próbie wyjaśnienia tajemnicy zła. Próba ta ma stanowić - jego zdaniem - „otwarcie okien" na perspektywy niebytu, które nie ustępuje ,otwarciu okien" na dziedzinę bytu.

Wediug Maritaina metafizyczny warunek aktu moralnie złego, ten warunek, jakim ma być brak odniesienia się do reguły moralnej, jest nihilizacją, unicestwianiem, wprowadzaniem nicości (the nihilation, le néantement) w pozytywne poruszenie Boże, które uaktywnia złą czynność albo złą decyzję, o ile jest czynnością lub decyzją, a więc o ile jest pewnym rodzajem rzeczy, bytu. Wskazane wprowadzenie nicości, wyprzedzające pod względem natury, w porządku ontologicznym, czynność moralnie złą ${ }^{155}$, ni e jest jeszcze złem albo brakiem mor a lnym. Jest to mera nagatio, szczelina, próżnia lub prosta luka w obrębie bytu, czyste przeciwieństwo do bytu lub dobra, nie wchodzącego w sferę naszych obowiązków. Gdyby to było zło moralne w sferze naszej woli, byłaby to już czynność wolna o ujemnej kwalifikacji moralnej, a wówczas tłumaczylibyśmy zło moralne wolnej czynności przez ta-

la règle; et cela de par la pure initiative de la volonté créée, à titre de cause première déficiente, - je ne dis pas de par l'action de la volonté créée, puisque à ce moment-là il n'y a encore rien de positif, il n'y a pas encore d'action, - je dis de par l'initiative et la liberté déficiente de la volonté créée". Jak nieco dalej zaznacza Maritain (s. 293), chodzi mu o inicjatywę, ,non pas d'un acte, mais d'une absence, d'une négation, de la non-considération actuelle de la règle". Zdaniem Maritaina, wyrażonym w tym eseju (s. 294), nie jest łatwo pojąć wolną inicjatywę, która nie jest czynnością, lecz inicjatywą nie działania, nie zwracania uwagi na regułę moralną, inicjatywą nieobecności.

154 Maritain odwoł̌uje się jeszcze do Sum. c. Gent., lib. III, a. 10 (od słów: „Relinquitur igitur quod morale vitium in solo actu voluntatis primo et principaliter invenitur ..." do końca artykułu) oraz do Sum. theol., I, qu. XLIX, a. 1, ad 3, i I-II, qu. LXXV, a. 1 , ad. 3.

155 Gdy idzie o stosunek czasowy nie zwracania uwagi na regułę moralną i grzesznego wyboru dokonanego w następstwie tego braku, to $\mathrm{w}$ Court traité de l'existence et de l'existant (s. 149) Maritain przyjął, że jedno i drugie dokonuje się w tym samym momencie. Natomiast w Dieu et la permission du mal skłonił się do innego ujęcia: , [...] le premier instant de non-considération de la règle survient, en ce qui concerne le temps, [...] au cours de l'ultimum tempus de la délibération, lequel ultimum tempus se termine à un premier instant du non-être de la délibération qui est le premier instant de l'être de l'acte d'élection peccamineux. Ainsi le premier instant du non-Étre de la considération de la règle ne coincide pas avec le premier instant du non-être de la délibération; il prend place un peu auparavant, pendant l'ultimum tempus de la délibération, la non-considération de la règle continuant pendant le reste de cet ultimum tempus, et ensuite" (s. 54; zob. jeszcze dalszy ciąg tekstu do końca n. 8). 
kież zło, co wprowadzałoby nas w błędne koło ${ }^{156}$. Ale choć nie zwracanie uwagi na regułę moralną nie jest z siebie czymś złym moralnie, to jednak, o ile jest luką w obrębie bytu czy we władzach działających, staje się negatywnie przyczyną zła moralnego, znajdując zastosowani e do czynności, która zostanie spełniona w następstwie owego braku ontycznego. Pozwolenie na przypadek zła moralnego mieści się $\mathrm{w}$ fakcie, że Bóg daje w kierunku dobra poruszenie, które może być zniweczone przez człowieka, jeżeli ten uchyli się przed nim w sposób wolny ${ }^{157}$.

3. Maritain utrzymuje zgodnie z ujęciem tradycyjnym, że, mimo upadków moralnych człowieka, plan jego dziejów jest ustalony przez Boga raz na zawsze od wieków. Według francuskiego tomisty jestestwa obdarzone wolną wolą mają w pewien sposób udział w określeniu tego planu. Mają mianowicie udział nie przez swą moc działania, gdyż od tej strony wszystko posiadają od Boga, ale przez to, że mogą być pierwszą przyczyną w linii niebytu, jak to wyżej zostało przedstawione. Bóg ustalając plan dziejów liczy się z tą przyczynowością człowieka o charakterze negatywnym. Nie można wprawdzie utrzymywać, żeby człowiek mógł być czynnikiem zmiany omawianego planu, niemniej jednak człowiek wchodzi w samo jego ułożenie przez to, że może Bogu odmówić posłuszeństwa.

W następstwie takiego ujęcia może Maritain utrzymywać, że jakkolwiek byłaby wielka doza materialnego czynnika widzialnego przy warunkowaniu dziejów ludźkich w świecie natury, dzieje te kształtują się przede wszystkim z krzyżowania się i wzajemnego przeplatania oraz konfliktu wolności niestworzonej i stworzonej. Są one jakby wymyślane w każdym momencie czasu przez zgodne lub niezgodne inicjatywy tych dwu wolności. Wolność stworzona psuje często kierunek ludzkich dziejów, ale wolność niestworzona potrafi wydobyć z obfitości zniszczeń jeszcze większą obfitość bytu. Jest to jej chwaią, gdyż ona jedna może tego dokonać.

156 W ten sposób rozumował Maritain w studium Saint Thomas d'Aquin et le problème du mal (De Bergson à Thomas d'Aquin ..., 285), dając wyraz przekonaniu (s. 287-288), że podejmuje stanowisko Akwinaty z De malo, qu. I, a. 3. Wskazane rozumowanie Maritain powtórzy w Court traité de l'existence et de l'existant (s. 148) i w Dieu et la permission du mal (s. 28, 29).

157 Wyrażenie: a breakable motion or activation (On the Philosophy of History, 120) lub une motion ou activation brisable au bien (Pour une philosophie de l'histoire, 130) stanowi u Maritaina rodzaj filozoficznego ekwiwalentu wyrażenia teologicznego: łaska dostateczna. Por. korektury i uściślenia, jakie francuski tomista wysunął w Dieu et la permission du mal (s. 57-59) w przedmiocie noty z Court traité de l'existence et de l'existant (s. 156-161), mającej za przedmiot Boże poruszenie, które może być zniweczone przez człowieka." 
W przedstawionym przez Maritaina obrazie stosunków między wolnością Bożą a wolnością ludzką w kształtowaniu historii budzi zastrzeżenia ujęcie metafizycznego warunku aktu moralnie złego, jakim jest wolne nie zwracanie uwagi na regułę moralną. Dokładniej się wyrażając powiemy, że zastrzeżenia budzi twierdzenie francuskiego tomisty, że 1. ów metafizyczny warunek jest to mera negatio, czyste przeciwieństwo do bytu lub dobra, i 2. że nie jest on jeszcze złem, brakiem moralnym.

1. Maritain nie spostrzega się najpierw, że nie myślenie aktualne o regule moralnej, gdy ono powinno mieć miejsce przed decyzją o charakterze etycznym, może stanowié tylko jedną, n e gatyw $\mathrm{n}$ ą stronę metafizycznego warunku spełnienia aktu moralnie złego. Wszak akt ten nie jest wyłącznie funkcją nie zwracania uwagi na regułę moralną, lecz ponadto dochodzi w nim do głosu pozytywne przylgnięciedo czegoś przeciwnego tej regule. W rzeczywistości egzystencjalnej człowieka działającego etycznie nie myślenie aktualne o regule moralnej staje się nie liczeniem z tą regułą dla czegoś $\mathrm{ni}$ e ty c znego. Nie jest to więc mera negatio, czyste przeciwieństwo do bytu lub dobra, którego realizacja nie byłaby naszym obowiązkiem. Przyczyna zła moralnego ma nie tylko charakter negatywny, lecz również i pozytywny.

O wolnym nie zwracaniu uwagi na regułę moralną możemy wtedy tak się wyrażać, jak to czyni Maritain, gdy wskazany brak bierzemy a bstrakcyjni e. Przy takim jego potraktowaniu nie musimy dopełniać go pozytywnym skierowaniem się do czegoś moralnie złego.

Ubocznie dodaję, że to, co zostało powiedziane o obecności nie tylko aspektu negatywnego, ale i pozytywnego $\mathrm{w}$ braku aktualnego odniesienia się do reguły moralnej, trzeba powtórzyć również i o złu moraln y m uwalniając jego teorię od jednostronności, jakie wystąpiły u św. Tomasza $\mathrm{z}$ Akwinu.

2. Jeżeli nie myślenie aktualne o regule morainej nie jest $\mathrm{w}$ relacji do decyzji typu etycznego prostą luką w obrębie bytu, jeżeli zawiera ono jeszcze podany wyżej element pozytywny - to ni e moż e być ne utralne z etycznego punktu widzenia, jak chce Maritain. Przystępowanie do decyzji bez odniesienia się do reguły moralnej nie może obejść się bez winy. Nie zwracanie uwagi na regułę moralną stanowi element składowy grzesznej decyzji.

Jest natomiast prawdą, że gdy do sprawy reguły moralnej podchodzimy abstrakcyjnie, możemy aktualne myślenie czy nie myśle- 
nie o tej regule traktować jakó $\mathrm{rzecz}$ obojętną pod względem etycznym. Możemy $w$ tej perspektywie pojęciowej utrzymywać, że nie jest się obowiązanym stale odnosić się aktualnie do reguły moralnej. Nie jest to nawet możliwe, jak już na to zwrócił uwagę św. Tomasz z Akwinu, który zaraz dodał, że przystąpienie do decyzji etycznej bez odniesienia się do reguły moralnej mieści w sobie pierwsze piętno zła moralnego ${ }^{158}$. Błąd Maritaina, który dość dowolnie wyinterpretował teksty Akwinaty, polega więc na tym, że to, co o aktualnym myśleniu lub nie myśleniu o regule moralnej jest prawdą w ujęciu abstrakcyjnym, wziął za prawdę w ujęciu konkretnym, dotyczącym przyczynowych uwarunkowań zła moralnego.

\section{§. 4. PROBLEM CELÓW NATURALNYCH HISTORII SWIATA ROZPATRYWANYCH PRZEZ MARITAINA W RELACJI DO CELU NADPRZYRODZONEGO CZEOWIEKA.}

1. Pisząc o celach naturalnych historii świata Maritain ma na uwadze cele, jakie narzucają się w odniesieniu do świata rozważanego w czystej perspektywie natury. Jego zdaniem cele tego rodzaju są trojakie.

$\mathrm{Na}$ pierwszym miejscu należy wymienić panow anie c złowieka nad przyrodą i zdobycie a utonomii ludzkiej. Przy tym celu chodzi nie tylko o dążenie do uwolnienia się spod panowania i przymusu wywieranego na człowieka przez naturę fizyczną, ale również o wysiłki zmierzające do wyzwolenia go spod ujarzmienia ze strony innych ludzi.

Dalszym celem naturalnym historii świata jest — według Maritaina rozwój różnorakich form aktywnościduchowejczłowieka, a specjalnie rozwój poznania na wszystkich jego stopniach (m. in. postęp w poznaniu prawa naturalnego) oraz rozwójaktywności artystycznej.

Trzeci wreszcie cel naturalny, jaki Maritain wymienia, jest to u k azanie wszystkich potencjalności natury ludzkiej. Cel ten narzuca się z tej racji, że człowiek nie jest czystym duchem, ale duchem złączonym z materią. Otóż jest rzeczą naturalną, by taki duch ujawniał sam siebie. A ponieważ człowiek obejmuje całe mnóstwo ukrytych potencjalności, jest rzeczą normalną, że stopniowo ujawnia swój świat wewnętrzny.

158 Oto zasadniczy tekst z De malo, qu. I, a. 3: „Hoc ipsum quod est non attendere actu ad talem regulam [regulam rationis et legis divinae] in se consideratam, non est malum nec culpa nec poena; quia anima non tenetur nec potest attendere ad huiusmodi regulam semper in actu; sed ex hoc accipit primo rationem culpae, quod sine actuali consideratione regulae procedit huiusmodi electionem..." 
Uwzględniając dane teologii Maritain przyjmuje, że realne cele naturalne historii świata zostały podniesione przez swą łączność z celem nadprzyrodzonym człowieka i jego cnotami nadprzyrodzonymi. To podniesienie wyraża się witalnymi i organicznymi relacjami do Królestwa Bożego.

Ale choć francuski tomista utrzymuje, że przy celach naturalnych historii świata nie chodzi o cel bezwzględnie najwyższy, to jednak podkreśla on, że jest to cel r e a ln y. Rzeczy doczesne są podporządkowane celowi nadprzyrodzonemu człowieka, ale są podporządkowane nie na sposób czystego środka. $\mathrm{Mają} \mathrm{one} \mathrm{pewną} \mathrm{wewnętrzną} \mathrm{wartość}$ oraz dobroc i wskutek tego są godne szukania dla $\mathrm{nich}$ samych. Cele naturalne historii świata mogą być więc uważane za względ ne cele ostateczne ${ }^{159}$.

2. Refleksje Maritaina nad celami naturalnymi historii świata jeszcze raz wskazują na to, że chrześcijańska filozofia historii tego tomisty jest w dużej mierze teologią historii. Maritain nie spostrzegł się, że mógi abstrahować od danych teologii dotyczących celu nadprzyrodzorego człowieka, skoro cele naturalne historii ludzkiej są — jak sam przyznaje - celami realnymi. Takie abstrahowanie nie doprowadziłoby do błędnego ujęcia zagadnienia celów historii ludzkiej. Doprowadziłoby jedynie - jak zauważyłby teolog - do c zęści o w e g o wyświetlenia tego zagadnienia. Lecz prawda filozoficzna nie musi być prawdą pełną. Filozof może mieć świadomość tego stanu rzeczy nawet niezależnie od informacji ze strony teologii.

Na korzyść Maritaina jako filozofa przemawia wszakże okoliczność, $\dot{z}$ e zdołał dostrzec, iż naturalne cele historii świata nie są czystymi środkami do celu nadprzyrodzonego człowieka, że mają pewną immanentną vartość, ze względu na którą mogą być względnie ostatecznymi celami. Dochodzi tu do głosu słuszna dążność do przyznania porządkowi naturalnemu względnej autonomii.

159 On the Philosophy of History, 123-127 (Pour une philosophie de l'histoire, 133-136). Por. Le Paysan de la Garonne, 65-67. 


\section{R E S U M E}

LA PHILOSOPHIE CHRETIENNE DE L'HISTOIRE SELON JACQUES MARITAIN (L'ÉTUDE CRITIQUE)

L'auteur nous présente son étude critique de la philosophie chrétienne de l'histoire de Jacques Maritain prenant en considération non seulement son On the Philosophy of History (New York, 1957), mais aussi l'ensemble de ses recherches à ce sujet. Il analyse la théorie et la méthodologie de la philosophie de l'histoire de Maritain ( $(1)$, les lois de l'histoire dans sa présentation (§2), sa conception des relations entre la liberté divine et la liberté humaine dans la formation de l'histoire (§ 3) et le problème des fins naturelles de l'histoire du monde considerées par le thomiste français en relation au but surnaturel de l'homme (§4). 